\title{
Street Vendors, Taxicabs, and Exclusion Zones: The Impact of Collateral Consequences of Criminal Convictions at the Local Level
}

\begin{abstract}
AMY P. MEEK*
Some of the most severe collateral consequences of criminal convictions are imposed through city and county ordinances and policies. This Article offers the first in-depth examination of these municipal policies, including permits and licensing ordinances, registration and exclusion zones, third-party background-check requirements, and local hiring policies. Some municipal ordinances, such as residential restrictions on sex offenders, impose far harsher sanctions than their state counterparts, effectively banishing certain individuals from the community. In addition, municipal licensing ordinances limit access to occupations-such as street vending, operating a food cart, or driving a taxicab-that offer valuable entrepreneurial opportunities to individuals with criminal convictions. Often invisible to defendants at the time of sentencing, these local policies have been used as a way to exile "undesirables" by effectively barring them from living, working, or participating in public life in their communities. This Article offers suggestions for legislative reform to address the patchwork of collateral consequences that can lead to exile at the local level. States may pass laws preempting municipal restrictions, or municipalities can lead the way by adopting collateral consequences ordinances (such as the one unanimously passed in New Haven, Connecticut) that mitigate the impact of these restrictions by setting uniform standards and informing attorneys and the public.
\end{abstract}

\section{TABLE OF CONTENTS}

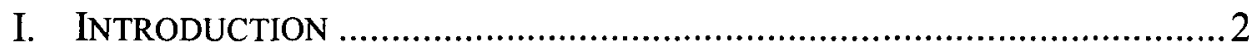

II. HISTORY AND OVERVIEW OF COLLATERAL CONSEQUENCES ................5

III. IMPACT OF COLLATERAL CONSEQUENCES AT THE LOCAL LEVEL ........ 11

A. Background Check Requirements for Licensing...................... 13

1. Licensing of Establishments Thought To Cause



2. Licensing of Occupations and Professions ........................ 15

3. The Impact of Collateral Consequences in Municipal Licensing ........................................................................... 18

B. Municipal Registration and Exclusionary Ordinances ............ 19

1. Municipal Registration Ordinances.................................... 20

2. Exclusionary Zoning Ordinances ..................................... 23

${ }^{*}$ ChildLaw Policy Clinical Teaching Fellow, Loyola University Chicago School of Law; J.D., Yale Law School, 2009; B.A., Swarthmore College, 2002. Former Reentry Coordinator for the City of New Haven, Connecticut, 2009 to 2012. Thanks to Ian Ayres, John Bronsteen, Atiba Ellis, Jeff Selbin, Joe Vavra, Anita Weinberg, and Michael Zimmer for valuable feedback. 
3. The Impact of Registration and Exclusionary Zoning ........29

C. Municipal Background Check Policies.................................... 32

1. Background Check Policies in Municipal Employment.......33

2. The Impact of Municipal Background Check Policies

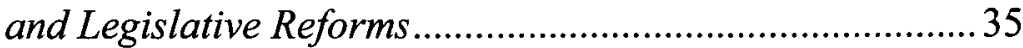

D. "Third-Party" Collateral Consequences...................................36

1. Landlord Background Checks ...........................................37

2. Employer Background Checks ..........................................39

3. The Impact of "Third-Party" Collateral Consequences

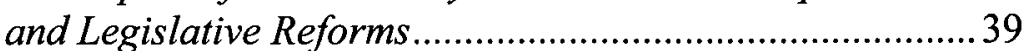

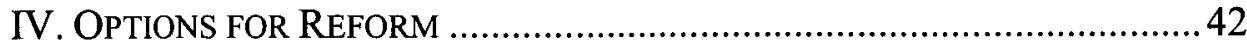

A. State Law Reforms for Municipal Collateral Consequences.... 42

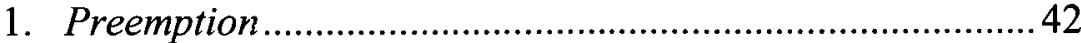

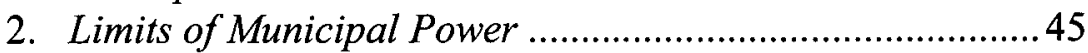

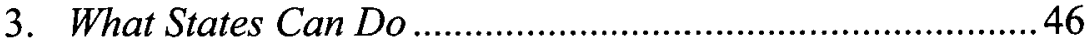

B. Using Municipal Ordinances To Address Collateral

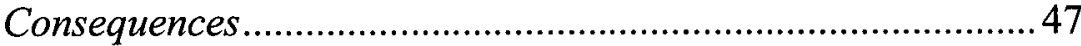

1. Municipal Standards for Imposing Collateral

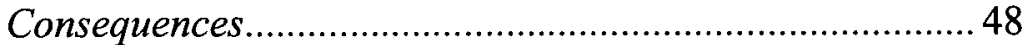

2. Municipal Collection of Collateral Consequences ..............50

3. Municipal Expungement of Records ...................................51

4. Why "Ban the Box" Suggests Collateral Consequences

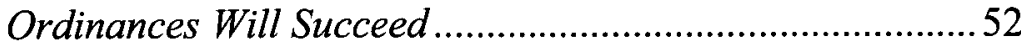

V. ConCLusion.

\section{INTRODUCTION}

Harold Williams used to sell drugs to earn a living. After his second conviction on felony narcotics charges, he was released on parole and resolved to turn his life around. In the past, he'd occasionally helped his girlfriend Danielle with her stand at the local flea market, where she used her street vendor's license to sell clothing, shoes, and sunglasses. Most employers rejected Harold because of his record, so he started devoting more time to street vending and discovered he liked it-not just the customer interaction and the entrepreneurial hustle, but also the pride of earning an honest living that he could show his young daughter. When Danielle found a new full-time job and wasn't able to work the stand on weekdays, Harold decided to apply for his own street vendor's license so he could work the stand full-time and maybe even expand the business. He could skirt the rules by working under Danielle's license without her around, but he didn't want to get in trouble; he wanted to play by the rules and build the business under his own name.

Harold applied to the City of New Haven for a street vendor's license but was denied because of his criminal record. New Haven's street vendor 
ordinance directed the police chief to determine whether the applicant was a "suitable person," based on factors including felony convictions within the last five years. Harold's record was three to four years old, so he was rejected out of hand. Undaunted, Harold asked his parole officer for support and reapplied a few months later, this time submitting evidence of rehabilitation with testimonials from loyal customers and letters from community supporters. When he was denied again, he started to get frustrated. What was the point in turning his life around if he'd only be judged for his record instead?

Harold's story ${ }^{1}$ illustrates the impact of the statutory and regulatory barriers faced by individuals reentering the community from incarceration. These barriers are often called collateral consequences, the indirect sanctions imposed on individuals with criminal convictions by statutes, codes, regulations, and policies at the federal, state, and local levels. ${ }^{2}$ Collateral consequences have wide-ranging effects not only on an individual's ability to secure employment ${ }^{3}$ or career-related licenses ${ }^{4}$ but also voting rights, ${ }^{5}$ immigration status, ${ }^{6}$ and eligibility for subsidized housing ${ }^{7}$ and welfare benefits, ${ }^{8}$ among other areas ${ }^{9}$ of his or her life.

${ }^{1}$ This account is drawn from the author's conversations with Harold Williams from 2011 to 2012. See also Thomas MacMillan, Hot Dog Harold Gets a Chance, NEw HAVEN INDEP. (Apr. 3, 2012, 6:41 AM), http://www.newhavenindependent.org/index.php/archives/ entry/hot_dog_harold_gets_a_chance/; ThinkActNewHavenCT, An Honest Living: Harold's Story, YOUTUBE (June 14, 2012), http://www.youtube.com/watch?v=UWGXLiIYtmc.

2 See, e.g., Michael Pinard, An Integrated Perspective on the Collateral Consequences of Criminal Convictions and Reentry Issues Faced by Formerly Incarcerated Individuals, 86 B.U. L. REv. 623, 624-25 (2006); Michael Pinard, Collateral Consequences of Criminal Convictions: Confronting Issues of Race and Dignity, 85 N.Y.U. L. REV. 457, 459-61 (2010) [hereinafter Pinard, Collateral Consequences]; Jenny Roberts, The Mythical Divide Between Collateral and Direct Consequences of Criminal Convictions: Involuntary Commitment of "Sexually Violent Predators," 93 MINN. L. REV. 670, 678 (2008).

${ }^{3}$ See, e.g., 42 U.S.C. $\$ 13041$ (c) (2012) (providing that employment in a federal or federally funded child care facility may be denied based on "[a]ny conviction for a sex crime, an offense involving a child victim, or a drug felony"). See generally Leroy D. Clark, A Civil Rights Task: Removing Barriers to Employment of Ex-Convicts, 38 U.S.F. L. REV. 193 (2004).

${ }^{4}$ See, e.g., 7 U.S.C. $\S 12 \mathrm{a}(3)$ (2012) (authorizing the Commodity Futures Trading Commission to deny an agriculture commodity dealer's license to any person convicted of a variety of enumerated felonies and misdemeanors). See generally Donald R. Stacy, Limitations on Denying Licensure to Ex-Offenders, 2 CAP. U. L. REV. 1 (1973).

${ }^{5}$ See, e.g., IOWA CODE ANN. $§ 48$ A.6 (West 2012) (disqualifying persons who have been convicted of a felony from voting and from registering to vote). See generally Richard $\mathrm{M}$. $\mathrm{Re} \&$ Christopher M. Re, Voting and Vice: Criminal Disenfranchisement and the Reconstruction Amendments, 121 YALE L.J. 1584, 1586-87 (2012); Jennifer Rae Taylor, Constitutionally Unprotected: Prison Slavery, Felon Disenfranchisement, and the Criminal Exception to Citizenship Rights, 47 GONZ. L. REV. 365, 378-80 (2011).

${ }^{6}$ Padilla v. Kentucky, 130 S. Ct. 1473, 1478-80 (2010).

${ }^{7}$ See, e.g., 42 U.S.C. $\S 13663$ (2012) (prohibiting admission to federally assisted housing for individuals subject to lifetime sex offender registration requirements). See generally NAT'L Hous. LAW PROJECT, AN AFFORdABLE HOME ON RE-ENTRY: FEDERALly 
Collateral consequences have attracted increased attention in recent years. Commentators have expressed concern about the reach and the inequities of collateral consequences, given the increasing numbers of individuals involved in the criminal justice system ${ }^{10}$ and its race and income disparities. ${ }^{11}$ This research has generally focused on the collateral consequences imposed at the state and federal level.

This Article seeks to highlight a category of collateral consequences-those imposed by municipal law ${ }^{12}$ - that has gone unexamined by the scholarly literature. The Article will argue that collateral consequences imposed at the local level can have far-reaching, often severe effects on individuals' ability to live, work, and engage in public life within their local communities. This Article will also offer suggestions for legislative reform, at the municipal as well as the state level, to mitigate these consequences and provide information about them to attorneys and the public.

Collateral consequences imposed at the local level affect vital issues of employment and housing. In some areas-such as residential restrictions on sex offenders-municipal ordinances may impose far harsher sanctions than their state counterparts, effectively banishing certain individuals from the community. In addition, municipal licensing ordinances regulate a number of

ASSISTED Housing AND PREVIOUSLy INCARCERATED INDIVIDUALS 7-13 (2008); Wendy J. Kaplan \& David Rossman, Called "Out" at Home: The One Strike Eviction Policy and Juvenile Court, 3 DUKE F. FOR L. \& SOC. CHANGE 109, 112-21 (2011).

${ }^{8}$ See, e.g., 21 U.S.C. $\$ 862 \mathrm{a}(\mathrm{a})$ (2012) (denying eligibility for food stamp and TANF benefits to individuals convicted of drug-related felonies); see also Sabra Micah Barnett, Collateral Sanctions and Civil Disabilities: The Secret Barrier to True Sentencing Reform for Legislatures and Sentencing Commissions, 55 ALA. L. REV. 375, 376-77 (2004).

${ }^{9}$ See, e.g., Gabriel J. Chin, The New Civil Death: Rethinking Punishment in the Era of Mass Conviction, 160 U. PA. L. REv. 1789, 1790 (2012) (arguing that the far-reaching and interlocking nature of collateral consequences amounts to a "new civil death"); Hanh H. Le, The "Padilla Advisory" and Its Implications Beyond the Immigration Context, 20 WM. \& MARY BILL RTS. J. 589, 591-93 (2011) (providing an overview of collateral sanctions in federal law).

${ }^{10}$ Michelle Natividad Rodriguez \& MaURice EMSEllem, NAT'l EMP'T LAW Project, 65 Million "NEEd NOT APPLY": THE CASE fOR REFORMING CRIMINAL BACKGROUND CHECKS FOR EMPLOYMENT 4 (2011); see also Written Testimony for Amy Solomon, Senior Advisor to the Assistant Attorney Gen., Office of Justice Programs, U.S. Dep't of Justice, to the Equal Emp't Opportunity Comm'n (July 26, 2011), available at http://www.eeoc.gov/eeoc/meetings/7-26-11/solomon.cfm.

${ }^{11}$ See, e.g., Michelle AleXander, THE NEW JIM CROW 1-18 (2010); Pinard, Collateral Consequences, supra note 2, at 516-17; see also EEOC, ENFORCEMENT GUIDANCE 915.002, ENFORCEMENT GUIDANCE ON THE CONSIDERATION OF ARREST AND CONVICTION RECORDS IN EMPLOYMENT DECISIONS UNDER TITLE VII OF THE CIVIL RIGHTS ACT OF 1964, at 8-10 (2012) (citing Griggs v. Duke Power Co., 401 U.S. 424, 431 (1971)).

12 This Article will use the terms "municipality" and "municipal" to refer to cities, towns, and counties and will generally not draw distinctions among these units of government. See Gerald E. Frug, The City as a Legal Concept, 93 HARV. L. REV. 1057, 1061 n.4 (1980) (using the term "city" "to refer to any other institution that exercises general governmental authority in an area smaller than, yet within, an American state"). 
activities - including street vending, operating a food cart, and driving a taxicab-that provide valuable entrepreneurial opportunities to reentering individuals. Over the last 150 years, these municipal ordinances have been employed to exclude "undesirables" like African-Americans and immigrants from full participation in their local communities. Local registration laws and residency restrictions have at times been openly justified by their proponents as intended to prevent certain populations from entering their cities or towns. Moreover, exclusionary ordinances that withstand legal challenges are often adopted at the state level, widening their scope.

This Article will address state law preemption as one way in which states can take action to simplify the patchwork of municipal collateral consequences. At the same time, municipalities can lead on this issue at the local level by passing collateral consequences ordinances. Such ordinances build on the success of municipal "Ban the Box" initiatives, which reduce barriers to employment by removing the "box" or question about past criminal records from initial employment applications. One model is the collateral consequences ordinance passed by New Haven, Connecticut, the first jurisdiction to pass a law mandating the collection and publication of the collateral consequences of a criminal conviction. Just as cities have been at the forefront of the "Ban the Box" movement, so too can they lead the way in enacting policies to examine and mitigate the collateral consequences of criminal convictions in America.

Part II of this Article will offer background on collateral consequences. Part III will address the impact of collateral consequences at the local level by highlighting some of the most common ordinances imposing them: licensing ordinances, registration and exclusionary zoning ordinances, background check requirements for municipal employment, and ordinances that require third parties (such as private employers and landlords) to impose collateral consequences. This Part will also outline some measures municipalities have begun to take to mitigate these collateral consequences. Part IV will offer suggestions for legislative reform at the state and municipal level, and Part V will conclude.

\section{HISTORY AND OVERVIEW OF COLLATERAL CONSEQUENCES}

While the issue of collateral consequences has gained increased prominence in recent years, it is by no means a new invention. Laws imposing civil disabilities as sanctions for criminal convictions are nearly as old as the criminal code. ${ }^{13}$ Over time, these sanctions evolved from direct civil punishments imposed at sentencing into indirect restrictions imposed through a patchwork of measures in constitutions, laws, and regulations. In the United

${ }^{13}$ Mirjan R. Damaska, Adverse Legal Consequences of Conviction and Their Removal: A Comparative Study, 59 J. CRIM. L. CRIMINOLOGY \& PoliCE SCI. 347, 350 (1968); see also Corey Rayburn Yung, Banishment by a Thousand Laws: Residency Restrictions on Sex Offenders, 85 WASH. U. L. REV. 101, 107 (2007) ("Expulsion has been used by governmental authorities since the time of the Code of Hammurabi in Babylon."). 
States, many modern collateral consequences began with municipal ordinances that were later adopted by states. Today, collateral consequences pose major barriers for ever-increasing proportions of Americans, due to increased incarceration rates and widespread availability of court and criminal records through online databases.

In early Roman society and Germanic tribes, outlawry could be imposed on those who committed particularly heinous crimes, requiring exile and the loss of all possessions and family rights. ${ }^{14}$ Ancient Greek citizens who committed crimes were subjected to "infamy," meaning they lost privileges of community membership including voting, attending assemblies, and serving in the army. ${ }^{15}$ In medieval Europe, individuals convicted of serious crimes were subjected to "civil death," under which they forfeited civil, family, and property rights. ${ }^{16}$ These punitive civil measures were imposed as part of the sentence or direct sanctions for a crime, whether through English common law or European codes. ${ }^{17}$

Early American colonial laws, modeled after the retributive European model of civil death, specifically restricted individuals with felony convictions from voting or holding public office. ${ }^{18}$ While medieval European codes and the English common law had imposed civil death only for especially heinous crimes, colonial laws singled out individuals who committed moral indiscretions as well. For example, voting rights could be forfeited after a conviction for drunkenness or fornication. 19

With the Declaration of Independence, states began to enact constitutions delineating who was eligible to vote, often restricting suffrage to those with "good character" 20 or without prior felony convictions. ${ }^{21}$ Unlike civil death, which had been imposed as a direct sanction for a serious criminal conviction, these disenfranchisement measures were now imposed outside of the sentencing and conviction process. ${ }^{22}$ By the time of the Civil War, most states in the Union had created laws or constitutions denying the vote to individuals convicted of serious crimes. ${ }^{23}$

The post-Civil War Reconstruction era marked the emergence of laws and policies expressly designed to deny privileges to African-Americans under the

${ }^{14}$ Damaska, supra note 13 , at 350.

15 Walter Matthews Grant et al., Special Project-The Collateral Consequences of a Criminal Conviction, 23 VAND. L. REV. 929, 941 (1970).

${ }^{16} \mathrm{Id}$. at 943 .

${ }^{17}$ Chin, supra note 9, at 1793-95.

18 See Grant et al., supra note 15 , at 950.

${ }^{19}$ Alec C. Ewald, "Civil Death": The Ideological Paradox of Criminal Disenfranchisement Law in the United States, 2002 WIS. L. REV. 1045, 1061-62.

${ }^{20} I d$. at $1061-63$.

${ }^{21}$ Howard Itzkowitz \& Lauren Oldak, Note, Restoring the Ex-offender's Right To Vote: Background and Developments, 11 AM. CRIM. L. REV. 721, 725 (1973).

${ }^{22}$ Ewald, supra note 19 , at 1062.

${ }^{23}$ Itzkowitz \& Oldak, supra note 21 , at 725. 
guise of excluding those with criminal convictions. ${ }^{24}$ Alongside measures like the poll tax and literacy test, Southern states carefully constructed new criminal disenfranchisement provisions to bar African-Americans from voting. ${ }^{25}$ For example, Mississippi's 1890 constitutional convention disenfranchised those convicted of crimes like burglary and theft but not those convicted of violent crimes like robbery or murder, on the theory that African-Americans were more likely to engage in "furtive" property crimes. ${ }^{26}$ Although facially neutral, these laws were often selectively enforced against African-Americans while whites with disqualifying convictions were allowed to vote. ${ }^{27}$

At the same time, the advent of professional licensing laws in the post-Civil War era ${ }^{28}$ created a new set of collateral consequences for individuals with criminal convictions. Licensing requirements were created for occupations like street peddling and liquor sales, as well as for professions like barbers, plumbers, and lawyers. Many states and municipalities prohibited the issuance of licenses for an applicant with a prior criminal record. ${ }^{29}$ While proponents argued that these requirements protected public safety, in practice they primarily excluded African-Americans and immigrants from access to the professions. ${ }^{30}$

This explosion in licensing laws, sometimes termed the "rise of the regulatory state," helped to engender the modern system of collateral consequences: pervasive, complex, and invisible at the time of sentencing. ${ }^{31}$ The dearth of information about collateral consequences in the criminal justice process was compounded by courts' interpretations of the Sixth Amendment right to legal counsel, which only required defense attorneys to advise their clients about consequences imposed at sentencing and not about the collateral consequences which could result from a guilty plea. ${ }^{32}$

${ }^{24}$ Margaret Colgate love et al., Collateral Consequences of Criminal CONVICTIONS: LAW, POLICY AND PRACTICE 8 (2013).

${ }^{25}$ Ewald, supra note 19 , at 1065.

${ }^{26}$ Ratliff v. Beale, 20 So. 865, 868 (Miss. 1896); see Gabriel J. Chin, Reconstruction, Felon Disenfranchisement, and the Right To Vote: Did the Fifteenth Amendment Repeal Section 2 of the Fourteenth Amendment?, 92 GEO. L.J. 259, 305 (2004).

${ }^{27}$ Chin, supra note 26 , at 306.

${ }^{28}$ Lawrence M. Friedman, Freedom of Contract and Occupational Licensing 1890 1910: A Legal and Social Study, 53 CALIF. L. REV. 487, 489 (1965); Edward P. Richards, The Police Power and the Regulation of Medical Practice: A Historical Review and Guide for Medical Licensing Board Regulation of Physicians in ERISA-Qualified Managed Care Organizations, 8 ANNALS HealTh L. 201, 206 (1999); see also Hawker v. New York, 170 U.S. 189, 191 n.1 (1898).

${ }^{29}$ See infra Part III.A for a history of occupational licensing.

${ }^{30}$ David E. Bernstein, Licensing Laws: A Historical Example of the Use of Government Regulatory Power Against African-Americans, 31 SAN DIEGO L. REV. 89, 96-103 (1994).

${ }^{31}$ See Chin, supra note 9, at 1799-1800, 1832.

32 See Margaret Colgate Love, Collateral Consequences After Padilla v. Kentucky:

From Punishment to Regulation, 31 ST. LoUIS U. PUB. L. REV. 87, 96-97 (2011). 
In the twentieth century, cities enacted ordinances to exclude individuals with criminal convictions from certain areas, starting in the 1930s with laws requiring those who passed through city limits to register with law enforcement. States followed this example by passing statewide registration laws that targeted individuals with certain types of criminal convictions.

In the mid-1960s and 1970s, legal reformers began calling attention to the issue of collateral consequences, ${ }^{33}$ and some states and courts began responding to the issue. ${ }^{34}$ The trend was quickly reversed by the 1980 s, however, with the rise of the "War on Drugs" and "tough on crime" policies such as mandatory sentencing laws. These policies led to increased rates of arrests and incarceration, particularly for African-Americans. ${ }^{35}$ States and municipalities began imposing harsher collateral consequences on broader groups, such as individuals convicted of misdemeanors. ${ }^{36}$ As sex offender registration laws proliferated throughout the states, ${ }^{37}$ municipalities stepped up their efforts by creating additional ordinances to restrict the residences and movement of those required to register. ${ }^{38}$

Today, over one in four American adults has an arrest or conviction record. ${ }^{39}$ Moreover, an estimated $7.5 \%$ of American adults have been convicted of a felony, including $23.3 \%$ of the African-American adult population. ${ }^{40}$ Although many of these records may be years or decades old, the trend towards computerized databases has made old convictions more accessible to background checks by employers and government agencies. ${ }^{41}$ Collateral consequences also continue to disproportionately affect minority populations, particularly African-Americans, due to their higher arrest and conviction rates. ${ }^{42}$

At the same time, the fact that $95 \%$ of convictions result from a guilty plea $^{43}$ raises concerns about whether defendants understand the full consequences of a decision to plead guilty. In 2003, the American Bar Association (ABA) renewed efforts to address this issue by issuing standards

${ }^{33}$ See generally Grant et al., supra note 15.

${ }^{34}$ LOVE ET AL., supra note 24, at 11.

35 ALEXANDER, supra note 11 , at 87-89.

${ }^{36}$ Lisa L. Sample \& Mary K. Evans, Sex Offender Registration and Community Notification, in SeX OfFender Laws: FaIled Policies, New DiRections 211, 212-14 (Richard G. Wright ed., 2009).

${ }^{37}$ LOVE ET AL., supra note 24, at 103.

${ }^{38}$ Id. at 109.

${ }^{39}$ See Solomon, supra note 10.

${ }^{40}$ Christopher Uggen, Jeff Manza \& Melissa Thompson, Citizenship, Democracy, and the Civic Reintegration of Criminal Offenders, 605 ANNALS AM. ACAD. POL. \& SOC. SCI. 281,288 (2006).

${ }^{41}$ James Jacobs \& Tamara Crepet, The Expanding Scope, Use, and Availability of Criminal Records, 11 N.Y.U. J. LEGIS. \& PUB. POL'Y 177, 183-84 (2008).

${ }^{42}$ See EEOC, supra note 11 , at 8-10.

${ }^{43}$ Thomas H. Cohen \& Tracey Kyckelhahn, Felony Defendants in Large Urban Counties, 2006, Bureau Just. Stat. Bull., May 2010, at 10. 
recommending that jurisdictions catalog their collateral consequences. ${ }^{44}$ The standards also encouraged prosecutors, defense attorneys, and judges to inform themselves about the relevant collateral consequences in particular cases. ${ }^{45} \mathrm{At}$ the direction of Congress, ${ }^{46}$ the National Institute of Justice contracted with the ABA to conduct a fifty-state survey of collateral consequences found in state laws and regulations. ${ }^{47}$ By creating a comprehensive database with respect to state and federal law, the fifty-state survey will ease the research burden that the ABA standards might otherwise impose on attorneys. ${ }^{48}$ For example, the ABA has already identified over 1100 places in New York state laws and regulations that impose collateral consequences in areas such as employment, licensing, government benefits, and education. 49

In 2009, the Uniform Law Commission addressed the issue through model state legislation called the Uniform Collateral Consequences of Conviction Act (UCCCA). ${ }^{50}$ The UCCCA is intended to address or mitigate collateral consequences in several ways. First, it addresses the standards by which collateral consequences are imposed, providing that collateral consequences only be imposed for convictions that are relevant to the benefit sought and that they should generally be interpreted as discretionary, not mandatory, sanctions. ${ }^{51}$ Second, the UCCCA commits the government to catalog and publish all of the collateral consequences within state laws and regulations, to be updated annually. ${ }^{52}$ Third, the UCCCA requires jurisdictions to advise defendants about the collateral consequences that may be relevant to their lives, both before and after conviction. ${ }^{53}$ Finally, the UCCCA includes detailed

${ }^{44}$ See ABA Standards for CRIminal Justice, Collateral Sanctions and Discretionary Disqualification of CONVICTED PERSONS, Standard 19-2.1 (3d ed. 2003). While the ABA standards refer generally to "jurisdictions," the accompanying commentary discusses only state and federal codes and does not address their applicability to local jurisdictions.

${ }^{45}$ See id. at Standard 19-2.1 cmt.; see also ABA COMM'N ON EFFECTIVE CRIMINAL SANCTIONS, REPORT To THE House of Delegates on REPRESENTATION RELATING to Collateral CONSEQuences 1 (2007) (urging "federal, state, territorial and local governments to assist defense counsel in advising clients ... [and] to encourage prosecutors to inform themselves of the collateral consequences that may apply in particular cases").

${ }^{46}$ Court Security Improvement Act of 2007, Pub. L. No. 110-177 $\S 510,121$ Stat. 2534, 2543-2544 (2008).

${ }^{47}$ See Project Description, ABA Collateral CONSEQUences, http://www.abacol lateralconsequences.org/description (last visited Feb. 10, 2014).

${ }^{48}$ Gabriel J. Chin, Making Padilla Practical: Defense Counsel and Collateral Consequences at Guilty Plea, 54 How. L.J. 675, 685 (2011); Love, supra note 32, at 120.

${ }^{49}$ National Inventory Collateral Consequences Conviction, ABA COLLATERAL CONSEQUENCES, http://www.abacollateralconsequences.org (select "New York" state, then select all categories in "Select Consequence Category" box; then select "any offense" in the "Select Offense Category" box) (last visited Apr. 8, 2013).

${ }^{50}$ LOVE ET AL., supra note 24, at 508.

51 UNIF. COLLATERAL CONSEQUENCES OF CONVICTION ACT $\S \S 7-8$ (2010).

52 Id. $\S 4$.

${ }^{53} I d . \S \S 5-6$. 
provisions by which states may offer relief from collateral consequences, including options for expunging records as well as selective relief mechanisms. 54

In 2010, the Supreme Court recognized the devastating impact that collateral consequences could have on defendants in Padilla v. Kentucky. ${ }^{55}$ As noted above, courts had long held that while the Sixth Amendment requires attorneys to advise defendants of the direct consequences of a guilty plea, they had no obligation to advise defendants of the collateral consequences likely to arise after completing their sentences. ${ }^{56}$ Furthermore, courts routinely held that a defendant given inaccurate advice about the collateral or direct consequences of a guilty plea could withdraw his or her plea under the Sixth Amendment. ${ }^{57}$ This "affirmative misadvice" exception further discouraged lawyers from advising their clients about the potential collateral consequences they faced for pleading guilty, even when such consequences were obviously relevant. In Padilla, however, the Supreme Court held that a defense attorney's failure to inform his client about the immigration consequences of a guilty plea could constitute ineffective assistance of counsel ${ }^{58}$ Instead of drawing a distinction between direct and collateral consequences, the court held that attorneys must advise their clients about any consequence that is "integral" to the plea because of its clear, automatic, and severe nature.$^{59}$ The Court criticized the "affirmative misadvice" exception as creating the "absurd" effect of giving lawyers "an incentive to remain silent on matters of great importance, even when answers are readily available." 60

The decision in Padilla touched off a wave of litigation contending that defense attorneys must inform their clients about other types of collateral consequences as well. ${ }^{61}$ For example, lower courts have held that failing to advise a client about sex offender registration requirements stemming from a guilty plea could constitute ineffective assistance of counsel. ${ }^{62}$ On the other hand, some courts have declined to interpret Padilla as requiring attorneys to advise their clients of the employment-related consequences of a guilty plea. ${ }^{63}$

${ }^{54} I d . \S \S 10-15$.

55 Padilla v. Kentucky, 130 S. Ct. 1473, 1481 (2010).

${ }^{56}$ See Love, supra note 32, at 96-97.

${ }^{57}$ Id. at 99.

${ }^{58}$ Padilla, 130 S. Ct. at 1486.

${ }^{59}$ Id. at $1480-82$.

${ }^{60}$ Id. at 1484.

${ }^{61}$ Malia Brink, A Gauntlet Thrown: The Transformative Potential of Padilla v. Kentucky, 39 FordHAM URB. L.J. 39, 44-45 (2011); Love, supra note 32, at 107-11.

62 See People v. Fonville, 804 N.W.2d 878, 894-96 (Mich. Ct. App. 2011); Taylor v. State, 698 S.E.2d 384, 388-89 (Ga. Ct. App. 2010).

${ }^{63}$ Thomas v. United States, No. RWT-10-2274, 2011 WL 1457917, at *4 (D. Md. Apr. 15, 2011); see also Commonwealth v. Abraham, 62 A.3d 343, 349-50 (Pa. 2012) (holding that counsel was not ineffective for failing to advise the defendant that pleading guilty would lead to his losing his public employee pension under state law). 
This renewed interest in mitigating collateral consequences and informing defendants, however, has not yet translated to legislative efforts at the state or federal level. To date, no state has enacted the UCCCA in its entirety ${ }^{64}$ and only one state, North Carolina, has partially adopted it. North Carolina's law, enacted in 2011 , creates a scheme by which individuals with less serious criminal convictions may apply for certificates of relief from certain collateral consequences. ${ }^{65}$ The law does not address the collection of collateral consequences or the standards by which they are imposed. 66

At the same time, the discussion about collateral consequences has largely ignored the issue of collateral consequences imposed by cities, towns, and counties. Although the ABA includes local jurisdictions in its standards, it has not published research or offered assistance to attorneys regarding local collateral consequences as it has at the state and federal level. Given that the Census counts over 3000 county governments and nearly 36,000 municipal, town, and township governments across the United States, ${ }^{67}$ it may be impractical to attempt a comprehensive national survey of collateral consequences in municipal codes of ordinances. However, the widespread availability of searchable city and county codes through proprietary websites and online databases ${ }^{68}$ suggests that many attorneys and judges have the capacity to determine relevant collateral consequences in their own local jurisdictions.

\section{IMPACT OF COLLATERAL CONSEQUENCES AT THE LOCAL LEVEL}

The lack of attention given to municipal collateral consequences is likely due not only to the sheer number of cities and towns but also to the limitations

${ }^{64}$ See Collateral Consequences of Conviction Act, UNIFORM L. COMMISSION, http://www.uniformlaws.org/Act.aspx?title $=$ Collateral $\% 20$ Consequences $\% 20$ of $\% 20$ Convicti on\%20Act (last visited Jan. 11, 2014). For a detailed discussion of the sections of the UCCCA, see infra Part IV.B. New Mexico's state legislature has twice passed versions of the UCCCA that were vetoed by the governor. See Gov. SUSANA MARTINEZ, N.M. SENATE EXECUTIVE MESSAGE No. 48 (Apr. 5, 2013), available at http://governor.state.nm.us/up loads/PressRelease/59fe4746f9614e8a8f62b0c5613a2f7f/SENATE\%20EXECUTIVE\%20M ESSAGE\%20NO.\%2048.pdf; Gov. SUSANA MARTINEZ, N.M. HOUSE EXECUTIVE MESSAGE No. 24 (Apr. 7, 2011), available at http://onlawyering.com/wp-content/uploads/2011/05/ VetoHB311-1.pdf.

${ }^{65}$ Act To Establish a Certificate of Relief, N.C. Sess. Law 2011-265, N.C. GEN. STAT. $\S \S 15 A-173.1$ to $-173.6(2011)$.

$66 \mathrm{Id}$.

${ }^{67}$ U.S. CENSUS BUREAU, 2012 CENSUS OF GOVERNMENTS: ORganizATION COMPONENT PRELIMINARY ESTIMATES (July 23, 2012), available at http://www2.census.gov/govs/cog/ 2012/formatted_prelim_counts_23jul2012_2.pdf.

${ }^{68}$ See, e.g., Paul A. Diller, The City and the Private Right of Action, 64 STAN. L. REv. 1109,1125 (2012) ("All major cities and counties post their codes on their proprietary websites, accessible to all Internet users, and online databases, such as Municode.com, aim to consolidate as many city and county codes as possible into one searchable location."). 
on the types of laws they can enact. Municipalities are "creature[s] of the state legislature"69 and have no powers outside of those conferred by the state. ${ }^{70}$ Therefore, a municipality generally cannot adopt an ordinance that goes beyond the powers granted to it by the state's laws, constitution, or home rule charter. ${ }^{71}$ Moreover, if the state law conflicts with or preempts a municipal ordinance governing a particular field, the municipal ordinance is void. ${ }^{72}$

Despite these limitations, municipalities generally have the power to regulate businesses and activities within their borders in order to preserve public health and welfare. ${ }^{73}$ In other situations, the state or federal government may expressly delegate authority to municipal governments or local agencies to carry out certain tasks. ${ }^{74}$ Municipalities also have the administrative and executive authority, of course, to appoint officers, agents, and employees to carry out their duties. ${ }^{75}$ Moreover, with the advent of home-rule powers, fortythree states have granted municipalities enhanced powers of self-government. ${ }^{76}$ Whether through home-rule or state-granted powers, municipal governments and agencies commonly impose collateral consequences on individuals with criminal convictions in four general ways: (1) licensing requirements that disqualify individuals based on past convictions or moral unfitness; (2) offender registries and zoning-style restrictions on areas where individuals may reside or enter, based on past arrests or convictions; (3) background check requirements for municipal employment; and (4) "third-party" collateral consequences that require private employers or landlords to conduct background checks or reject

${ }^{69}$ EUGENE MCQUILLIN, THE LAW OF MUNICIPAL CORPORATIONS $§ 3: 2$ (3d ed., updated July 2012).

${ }^{70} \mathrm{Id} . \S 10: 3$.

${ }^{71} I d$. In a few states, courts have recognized certain limited "inherent powers" of selfgovernment held by municipalities. See id.

${ }^{72}$ Id. $\& 21: 32$.

${ }^{73} \mathrm{Id} . \S 10: 29$.

${ }^{74}$ This Article will not address collateral consequences imposed by public housing authorities or local subsidized housing providers, such as background-check policies and bans on residence for individuals convicted of certain types of offenses. Such policies are governed by federal laws and regulations rather than by municipal ordinances, although local public housing authorities and local subsidized housing providers have broad discretion to develop their own policies regarding criminal records for prospective or current tenants. The impact that such policies can have on lower-income individuals with criminal records who seek affordable housing, however, suggests the importance of understanding the background-check policies of the public housing authorities and subsidized housing providers on a local community level. See, e.g., NAT'L HOUSING LAW PROJECT, supra note 7, at 92-106; Marie Claire Tran-Leung, SARgent Shriver Nat'l Ctr. ON PoverTy Law, WhEN DisCRETION MEANS DENIAL: THE USE OF CRIMINAL RECORDS TO DENY LOW-INCOME PEOPLE ACCESS TO FEDERALLY SUBSIDIZED HOUSING IN ILLINOIS 2-5 (2011).

${ }^{75}$ MCQUILLIN, supra note 69, § 10:44.

76 Wayne A. Logan, The Shadow Criminal Law of Municipal Governance, 62 OHIO ST. L.J. 1409, 1423 (2001). 
individuals with criminal records. ${ }^{77}$ This Part will discuss these general categories of municipal collateral consequences and the depth of their impact on individuals reentering their communities after arrest or incarceration.

Some of these restrictions may play a meaningful role in protecting public safety, such as requiring criminal background checks for aspiring police officers. However, this Part will argue that these restrictions often go beyond excluding those with relevant criminal histories, instead disproportionately affecting other traditionally marginalized populations such as the poor, AfricanAmericans, and immigrants. While courts have largely upheld these types of restrictions as within the realm of traditional public health and welfare regulation, they can prevent individuals from finding employment or a place to live, and limit their ability to engage in public life within their local communities. Moreover, where local ordinances have been upheld by courts, they may become models for similar state laws. Some municipalities have begun enacting ordinances that recognize and seek to limit certain barriers in employment and housing, suggesting a path for broader legislative reform of municipal collateral consequences.

\section{A. Background Check Requirements for Licensing}

Today, restrictions on the issuance of permits and licenses ${ }^{78}$ are frequently cited as a key source of barriers to employment for individuals with criminal convictions. ${ }^{79}$ Yet the literature addressing collateral consequences has largely ignored municipal licensing regimes, despite their widespread role in the regulation of businesses and occupations. ${ }^{80}$ Municipal licensing ordinances

${ }^{77}$ Although the distinction between "direct" and "collateral" consequences is an artificial one, this Article will not address municipal ordinances that impose additional direct sanctions on individuals arrested or convicted for certain crimes. This includes, for example, local penal ordinances which criminalize "petty offenses" or lengthen sentences beyond those provided by state law. See id. at 1433-36. By the same reasoning, this Article will not address municipal civil forfeiture ordinances, which allow for the seizure of vehicles and property connected to a broad range of crimes such as driving under the influence, drug transactions, and prostitution. See $i d$. at 1432 . For a contrary viewpoint that classifies civil forfeiture proceedings as collateral consequences because they proceed independent of criminal actions see LOVE ET AL., supra note 24 , at 153 . Because many municipal civil forfeiture ordinances have been struck down by courts as preempted by state law, however, they are likely to have less far-reaching effects than the policies discussed in this Article. See, e.g., City of L.A. v. 2000 Jeep Cherokee, 72 Cal. Rptr. 3d 252, 256 (Ct. App. 2008); City of Springfield v. $\$ 10,000.00$ in U.S. Currency, 767 P.2d 476, 478 (Or. Ct. App. 1989); Linn Cnty. v. 22.16 Acres of Real Prop., 767 P.2d 473, 475-76 (Or. Ct. App. 1989).

${ }^{78}$ This Article will use the terms "permit" and "license" interchangeably. MCQUILLIN, supra note $69, \S 26: 2$.

${ }^{79}$ See Chin, supra note 9, at 1802; W. Brooke Graves, Professional and Occupational Restrictions, 13 TEMP. L.Q. 334, 346 (1939); Karol Lucken \& Lucille M. Ponte, A Just Measure of Forgiveness: Reforming Occupational Licensing Regulations for Ex-offenders Using BFOQ Analysis, 30 LAW \& POL'Y 46, 53-54 (2008).

${ }^{80}$ See MCQUILLIN, supra note 69, § 26:65. 
generally regulate occupations that are thought to infringe on community morals or local order (such as liquor-serving establishments or dance halls) or that occupy local rights-of-way (such as street carts and taxicabs) ${ }^{81}$ This Section offers a brief overview of the history of municipal licensing ordinances as well as challenges to the collateral consequences they impose, and discusses the barriers they create to employment for individuals with criminal convictions.

\section{Licensing of Establishments Thought To Cause Nuisances}

Licensing laws first arose through liquor licensing efforts in the latter half of the nineteenth century, accompanying the rise of temperance societies in the United States. ${ }^{82}$ While some states took on licensing laws themselves, many left the task of regulation up to local cities and towns. ${ }^{83}$ The City of San Francisco, for example, passed an ordinance in 1878 requiring the consent of the board of police commissioners to obtain a retail liquor license. ${ }^{84}$ The city's authority to enact the ordinance was affirmed by the Supreme Court, which justified the denial of a liquor license to an applicant on the grounds that his wife had been previously arrested for stealing from visitors to their saloon. ${ }^{85}$ The Court held that the ordinance furthered the goal of enforcing public morality as well as reducing crime: "The statistics of every state show a greater amount of crime and misery attributable to the use of ardent spirits obtained at these retail liquor saloons than to any other source." 86

Soon, states and municipalities were amending liquor licensing ordinances to exclude individuals with criminal records, fueled by ongoing concerns about crime and morality and influenced by widespread perceptions that immigrants and non-whites were to blame for the problems of intemperance. ${ }^{87}$ In 1893, for example, San Francisco modified its ordinance to expressly prohibit the issuance of a liquor license to any person with a past felony conviction. ${ }^{88}$ The California Supreme Court upheld the ordinance, reasoning that using a felony as a measure of moral character was within the government's police power to protect the public. 89

Throughout the late nineteenth and early twentieth century, municipalities began requiring licenses for other businesses thought to create nuisances or pose

${ }^{81}$ See John J. Mortimer \& Patrick W. Dunne, Grant and Revocation of Licenses, 1957 U. ILL. L.F. 28, 41-42.

82 James Samuelson, The History of Drink: A ReVIEw, Social, SCIENTIFIC, AND POLITICAL 208-09, 240 (1878).

${ }^{83} \mathrm{Id}$. at 217.

${ }^{84}$ Foster v. Bd. of Police Comm'rs of S.F., 37 P. 763, 764 (Cal. 1894).

${ }^{85}$ Crowley v. Christensen, 137 U.S. 86, 95 (1890).

${ }^{86} \mathrm{Id}$. at 91 .

${ }^{87}$ SAMUELSON, supra note 82, at 205.

88 Foster, 37 P. at 764.

${ }^{89}$ Id. at 765 . 
a threat to public morality. Ordinances particularly focused on those businesses-like dance halls and pool rooms - that were most associated with licentiousness among African-Americans and women. ${ }^{90}$ Between 1885 and 1914, for example, at least seventeen major cities proposed or enacted ordinances requiring the licensing of dance halls. ${ }^{91}$

Today, municipal ordinances commonly require licenses for dance halls, liquor-serving establishments, arcades, pool halls, bowling alleys, movie theaters, massage parlors, and adult-oriented businesses. ${ }^{22}$ These licensing ordinances often include a criminal background check requirement, and may either explicitly exclude individuals convicted of certain criminal convictions or implicitly exclude them through a requirement that applicants be of "good moral character."93 These collateral consequences have been upheld by courts even when they impose broad bans on criminal records, on the grounds that communities have a legitimate purpose in ensuring that businesses which may "pose a significant threat to the peace of the community" are run by "persons of integrity with respect for the law."94

Even seemingly vague requirements regarding moral character have been upheld when they govern licensing for businesses thought to create potential neighborhood nuisances. For example, the Supreme Court held that a city ordinance licensing coin-operated arcades was not void for vagueness when it required the city's police chief to evaluate the applicant's character, including convictions for crimes involving moral turpitude and "connections with criminal elements." 95 Similarly, the Supreme Judicial Court of Maine held that a city's refusal to issue a restaurant license to an individual on grounds that he lacked "good moral character" was justified in part by the fact that he had two convictions over twenty years ago for "serious crimes involving moral turpitude."96

\section{Licensing of Occupations and Professions}

Building on the trend of requiring businesses to obtain licenses to protect public morality, broader professional licensing laws proliferated throughout

${ }^{90}$ See, e.g., Georgina Hickey, Waging War on "Loose Living Hotels" and "Cheap Soda Water Joints": The Criminalization of Working-Class Women in Atlanta's Public Space, 82 GA. HIST. Q. 775, 776-77 (1998); Gregory Mixon, "Good Negro-Bad Negro": The Dynamics of Race and Class in Atlanta During the Era of the 1906 Riot, 81 GA. HIST. Q. 593, 600-01 (1997).

${ }^{91}$ Elisabeth I. Perry, "The General Motherhood of the Commonwealth": Dance Hall Reform in the Progressive Era, 37 AM. Q. 719, 729-30 (1985).

92 MCQUILLIN, supra note $69, \S \S 26: 154.46$ to .59 .

93 See, e.g., Darks v. City of Cincinnati, 745 F.2d 1040, 1042 (6th Cir. 1984).

${ }^{94}$ Id. at 1043.

${ }^{95}$ City of Mesquite v. Aladdin's Castle, Inc., 455 U.S. 283, $289-92$ (1982).

${ }^{96}$ Chequinn Corp. v. Mullen, 193 A.2d 432, 436 (Me. 1963). 
states and municipalities in the first half of the twentieth century. ${ }^{97}$ Although their stated justifications were to protect the public, many licensing regulations were passed after significant lobbying by trade associations seeking to keep others out of the profession. ${ }^{98}$ For example, taxicab licensing arose during the Great Depression after out-of-work individuals flocked to become drivers, given the low start-up costs required for the job. ${ }^{99}$ Trade associations of established drivers responded by lobbying for ordinances to limit entry. 100 Some of the professions for which licenses became required during this period, such as photographers and barbers, have a seemingly tenuous connection to public health and safety. ${ }^{101}$ Facially neutral licensing regulations were often used to discourage or exclude minority groups, particularly African-Americans, from entering these professions. ${ }^{102}$

Many of these licensing laws included restrictions or outright bans on individuals with criminal records, sometimes more as a convenient way of excluding potential competitors than based on any relevant concern for public safety. 103 Others required that the applicant demonstrate "good moral character," which could eliminate from consideration those with misdemeanor convictions or even only an arrest record. ${ }^{104}$

Although most professional licensing laws were passed by states, municipalities began to license occupations as well, particularly those found on local rights-of-way such as street vendors, door-to-door peddlers, food carts, and taxicabs. These municipal licensing ordinances drew authority from the traditional municipal regulation of public markets' hours and location. ${ }^{105}$ In many cases, these licensing ordinances targeted occupations-such as street or pushcart vendors - that were associated with immigrants and the poor, seeking

${ }^{97}$ Frank Hanft \& J. Nathaniel Hamrick, Haphazard Regimentation Under Licensing Statutes, 17 N.C. L. REV. 1, 1-3 (1938); see also Daniel B. Hogan, The Effectiveness of Licensing: History, Evidence, and Recommendations, 7 LAW \& HUM. BEHAV. 117, 120 (1983); Simon Rottenberg, The Economics of Occupational Licensing, in NAT'L BUREAU OF ECON. RESEARCH, ASPECTS OF LABOR ECONOMICS 3, 4-6 (1962).

${ }^{98}$ Hanft \& Hamrick, supra note 96, at 4.

${ }^{99}$ Lee A. Harris, Taxicab Economics: The Freedom To Contract for a Ride, 1 GEO. J.L. \& PUB. POL'Y 195, 205-06 (2002).

100 Id. at 206.

101 Friedman, supra note 28, at 520-24; Hanft \& Hamrick, supra note 97, at 3-4.

${ }^{102}$ Timothy Sandefur, Equality of Opportunity in the Regulatory Age: Why Yesterday's Rationality Review Isn't Enough, 24 N. ILL. U. L. REV. 457, 487-95 (2004); see also Bernstein, supra note 30, at 94-103.

103 See James W. Robinson, Occupational Licensing, the Ex-offender, and Society, 31 JUST. SYS. J. 69, 71 (1975); Stacy, supra note 4, at 6.

${ }^{104}$ Anthony C. Thompson, Navigating the Hidden Obstacles to Ex-offender Reentry, 45

B.C. L. REV. 255, 281-82 (2004).

105 Daniel M. Bluestone, "The Pushcart Evil": Peddlers, Merchants, and New York City's Streets, 1890-1940, 18 J. URB. HiST. 68, 69 (1991). 
to eliminate them from public view on the grounds that the carts caused congestion and blight. ${ }^{106}$

Whether a particular occupation is licensed by the state or by municipalities can differ by region and by profession. For example, taxicab licensing is regulated at the municipal level in all but three states, where state legislatures have chosen to regulate the field. ${ }^{107}$ Other occupations, such as general contractors or electricians, are often regulated at the state level, but may be licensed by municipalities as well. ${ }^{108}$

As with other professional licensing laws, these municipal licensing ordinances frequently include restrictions on applicants' criminal convictions or "good moral character" requirements. 109 For example, the City of Frostproof, Florida, prohibits issuing a peddler's license to anyone who has ever been convicted of a felony. ${ }^{110}$ Indianapolis prohibits anyone convicted of a felony or misdemeanor involving violence towards another person from being granted a taxicab license, ${ }^{111}$ while Spokane, Washington, requires applicants to submit an affidavit affirming that they have not been convicted of several types of offenses, including offenses involving moral turpitude and felonies within the last ten years. ${ }^{112}$ New York City requires that general contractors and others engaged in the building trades obtain a license and that they be of "good moral character,"113 which has been interpreted to exclude applicants with prior criminal convictions. ${ }^{114}$ More recently, fears about individuals convicted of sex offenses have spurred several cities to pass licensing ordinances for ice cream trucks that specifically ban individuals required to register as sex offenders. ${ }^{115}$

These licensing restrictions have been frequently upheld by courts as justifiable regulations protecting public health and safety. ${ }^{116}$ For example, the Court of Appeals of Maryland upheld the denial of a taxicab license by the City of Baltimore on the grounds that the applicant had previously been convicted of disorderly conduct on three occasions for participating in unruly student

${ }^{106} I d$. at $75-80$.

${ }^{107}$ Harris, supra note 99 , at 196 n.3.

108 MCQUILLIN, supra note $69, \S \S 26: 142$ to 143 ; see, e.g., Jim Merkel, Checking Out the Contractors, GRANITE CITY PRESS-RECORD, Aug. 15, 2012, at A4.

${ }^{109}$ See, e.g., Nick Dranias, The Local Liberty Charter: Restoring Grassroots Liberty To Restrain Cities Gone Wild, 3 PHX. L. REV. 113, 136 (2010).

${ }^{110}$ FrostPRoOF, Fla., CODE $§ 14-22$ (2012).

${ }^{111}$ INDIANAPOLIS, IND., CODE $\S 996-22$ (2012). The restriction does not apply to individuals who already had a taxicab license at the time the ordinance became effective.

112 SPOKANE, WASH., CODE $\S 10.34 .120$ (2011).

113 N.Y.C., N.Y., ADMIN. CODE $§ 28-401.6$ (2008).

${ }^{114}$ Duffy v. Int'l Union of Operating Eng'rs Local 14-14B, 795 F. Supp. 2d 246, 255 (E.D.N.Y. 2011).

115 Jeff Martin, Push on To Inspect Ice Cream Vendors' Pasts, USA TODAY, http://usatoday30.usatoday.com/news/nation/2008-05-11-ice-cream-vendors_N.htm?csp=1 (last updated May 12, 2008,7:28 AM).

116 Grant et al., supra note 15 , at 1004. 
protests, and had undergone psychiatric treatment. ${ }^{117}$ Such restrictions are rarely struck down unless they are applied inconsistently. ${ }^{118}$ For example, the D.C. Court of Appeals overturned the denial of a vendor's license to an applicant who had provided evidence to demonstrate his rehabilitation from his conviction two years earlier, but noted that the denial would likely have been upheld had the licensing agency issued written guidelines relating the types of criminal convictions relevant to the license sought. ${ }^{119}$

\section{The Impact of Collateral Consequences in Municipal Licensing}

Licensing restrictions have been identified as one of the key types of collateral consequences about which attorneys should advise defendants facing criminal charges. ${ }^{120}$ Whether imposed at the municipal, state, or federal level, licensing restrictions pose major barriers to employment. ${ }^{121}$ Moreover, the collateral consequences of municipal licensing ordinances have particularly farreaching implications for the ability of individuals with criminal convictions to earn a livelihood and to participate in the public lives of their communities. While municipalities issue a more limited range of permits and licenses than states, the nature of these regulations - which address the use of public rightsof-way and potential threats to community order and moralitydisproportionately affect underprivileged populations who are more likely to have contact with the criminal justice system. Prior to passing a collateral consequences ordinance, the City of New Haven, Connecticut, examined its records of food cart applications and found that around one in seven applicants were rejected on the grounds of a past criminal record. ${ }^{122}$

Regulations on taxicabs, street vending, and food carts affect low-income minority populations in two major ways. First, these occupations are

${ }^{117}$ Kaufman v. Taxicab Bureau, Balt. City Police Dep't, 204 A.2d 521, 524-25 (Md. 1964).

${ }^{118}$ See, e.g., Miller v. Carter, 547 F.2d 1314, 1316 (7th Cir. 1977) (voiding on equal protection grounds a Chicago ordinance permanently barring individuals convicted of felonies or crimes involving moral turpitude within the previous eight years from receiving a chauffeur's license, because the ordinance allowed individuals who already possessed licenses to retain them if convicted of the same crimes).

${ }^{119}$ Miller v. D.C. Bd. of Appeals \& Review, 294 A.2d 365, 370 (D.C. 1972).

${ }^{120}$ McGregor Smyth, Holistic Is Not a Bad Word: A Criminal Defense Attorney's Guide to Using Invisible Punishments as an Advocacy Strategy, 36 U. TOL. L. REV. 479, 498 (2005) (suggesting that defense attorneys seeking to triage the key collateral consequences faced by clients should ask four questions, one of which is "Are you a public employee or do you hold an employment license?").

${ }^{121}$ Bruce E. May, The Character Component of Occupational Licensing Laws: A Continuing Barrier to the Ex-felon's Employment Opportunities, 71 N.D. L. REV. 187, 206 (1995); see also Clark, supra note 3, at 195.

122 Press Release, City of New Haven, Building on the Success of Ban the Box, Mayor DeStefano Announces New Reentry Initiative Proposal (Jan. 12, 2012), http://www.cityof newhaven.com/Mayor/ReadMore.asp?ID=\{9BF32A73-A87E-4CF9-8052-E19D227E1740 $\}$. 
entrepreneurial activities with low barriers to entry; they require little formal education and a relatively small capital investment. ${ }^{123}$ This makes them an excellent fit for those who face barriers to traditional employment, including individuals with criminal convictions and minority populations who have traditionally faced discrimination by employers. ${ }^{124}$ For those who have been economically marginalized, occupations like street vending can help build capital and knowledge about how to operate a business. ${ }^{125}$

Second, sealing off these occupations from individuals with criminal convictions can have a more insidious effect-that of sealing off the public sphere. These occupations are uniquely within the public eye, as they literally occupy public streets and sidewalks while interacting with the public. Regina Austin has argued that street vending offers the opportunity for AfricanAmericans to "build a more viable black public sphere." 126 Similarly, street vendors in Los Angeles predominantly gather in Latino neighborhoods and are seen as perpetuating customs from Latin America. ${ }^{127}$ Efforts to limit licensing for street vendors have been associated with efforts to prevent minorities, immigrants, and the poor from "blighting" public streets. 128 While criminal background check policies have been upheld as permissible public safety regulations, responsible policies should refer to relevant convictions only and clearly outline the standards for relevance.

\section{B. Municipal Registration and Exclusionary Ordinances}

Numerous municipalities have enacted ordinances that require individuals with certain convictions to register with law enforcement, or that ban those individuals from entering or passing through certain zones. These ordinances are rooted in municipal zoning powers, which were first used to pass zoning and town-planning ordinances in the early twentieth century. ${ }^{129}$ These regulations were justified as part of municipalities' police powers to protect public health and welfare. ${ }^{130}$

As with licensing ordinances, town-planning policies were often used to exclude "undesirable" populations from the local community under the pretense

${ }^{123}$ See, e.g., Timothy Sandefur, Can You Get There from Here?: How the Law Still Threatens King's Dream, 22 LAW \& INEQ. 1, 20 (2004).

${ }^{124}$ Gregg W. Kettles, Regulating Vending in the Sidewalk Commons, 77 TEMP. L. REV. 1, 22-23 (2004).

125 Regina Austin, "An Honest Living": Street Vendors, Municipal Regulation, and the Black Public Sphere, 103 YALE L.J. 2119, 2123 (1994).

126 Id. at 2131.

127 Kettles, supra note 124 , at 41.

128 Richard C. Schragger, The Limits of Localism, 100 Mich. L. REV. 371, 455 (2001); Bluestone, supra note 105 , at 74 .

${ }^{129}$ See, e.g., Town of Windsor v. Whitney, 111 A. 354, 356 (Conn. 1920); Comment, The Constitutionality of Zoning Laws, 32 YALE L.J. 833, 833-35 (1923).

${ }^{130}$ Town of Windsor, 111 A. at 356. 
of public safety. Starting with a 1911 Baltimore ordinance, cities enacted explicitly racial "segregation ordinances" that zoned blocks or neighborhood districts into white and non-white areas. ${ }^{131}$ After the Supreme Court invalidated racial segregation zoning ordinances in 1917 on the grounds that they violated the Due Process Clause of the Fourteenth Amendment, ${ }^{132}$ many communities turned to more facially neutral measures to accomplish the same goal. ${ }^{133}$

While today's municipal registration and exclusionary zoning ordinances draw on modern theories about crime control, they share common motivations with historical efforts by local governments to exclude poor or undesirable populations from their communities. ${ }^{134}$ This Section will discuss the history of municipal registration ordinances, which require individuals convicted of certain offenses to register with local law enforcement, as well as exclusionary zoning ordinances, which prohibit registered individuals from entering or residing in certain areas.

\section{Municipal Registration Ordinances}

While offender registration requirements have gained prominence in recent decades through the rise of state and federal sex offender registration and notification laws, they were pioneered by municipalities in the 1930s. The first municipal registration ordinances required persons with any type of conviction, whether residing or passing through city limits, to register with local law enforcement. ${ }^{135}$ These municipal ordinances were fueled by concerns about outof-state "gangsters" flooding into local communities. 136 The passage of municipal registration ordinances often had a "ripple effect" in communities: Once one city passed a registration ordinance, neighboring cities soon followed suit in order to avoid a potential influx of undesirable residents from other communities. 137

By the 1950 s, at least forty-seven cities had enacted general registration ordinances. The policies had also filtered up to five states, which enacted more limited registration laws targeting only individuals with certain types of convictions (such as California's sex offender registration law enacted in

${ }^{131}$ T.B. Benson, Note, Segregation Ordinances, 1 VA. L. REG. (N.S.) 330, 330 (1915);

Rachel D. Godsil, Race Nuisance: The Politics of Law in the Jim Crow Era, 105 MiCH. L. REV. 505, 539 (2006).

132 Buchanan v. Warley, 245 U.S. 60, 81 (1917).

133 Charles S. Mangum, JR., The Legal Status of THE Negro 142-48 (The Lawbook Exchange 2000) (1940).

134 Wayne A. Logan, Constitutional Collectivism and Ex-offender Residence Exclusion Laws, 92 IOWA L. REV. 1, 10-12 (2006).

135 Wayne A. Logan, Sex Offender Registration and Community Notification: Past,

Present, and Future, 34 NEW ENG. J. ON CRIM. \& CIV. CONFINEMENT 3, 4 (2008).

${ }^{136}$ Id.; see also LOVE ET AL., supra note 24, at 103.

${ }^{137}$ LOVE ET AL., supra note 24 , at 63-65. 
1949). ${ }^{138}$ The spread of general municipal registration ordinances was halted, however, by several high-profile court decisions in the 1950s and 1960s. First, in 1957 the Supreme Court ruled that Los Angeles' felon registration ordinance violated due process requirements, as applied to a woman who had long lived in the city with no notice and no actual knowledge of her duty to register. ${ }^{139}$ The Court noted that the registration requirement was triggered by mere presence in the city and that it imposed criminal penalties without any mechanism for notifying individuals who entered the city that they might be required to register, or any requirement of actual or probable knowledge on the defendant. ${ }^{140}$ Next, two state supreme courts ruled that general municipal criminal registration ordinances were preempted by state law. In 1960, the California Supreme Court voided the same Los Angeles ordinance entirely on the grounds that it was preempted by the state's comprehensive regulatory schemes regarding registration and supervision of individuals with criminal records, including the statewide sex offender registration law. ${ }^{141}$ Similarly, in 1969 the Supreme Court of New Jersey voided the borough of Belmar's general offender registration ordinance, finding that it was preempted both by the state's registration law for drug offenders and also by the state's overall policy of rehabilitating offenders through its parole and probation systems. ${ }^{142}$ The court further noted that the city's ordinance appeared to have little effectiveness, as it had resulted in a mere handful of registrations over the four years since it had been enacted. 143

In the wake of a handful of high-profile assaults and abductions of children in the late 1980 s and early 1990 s, states began enacting new registration laws targeting individuals convicted of sex offenses. ${ }^{144}$ The federal government began requiring states to establish such registries in 1994 with the passage of the Jacob Wetterling Crimes Against Children and Sexually Violent Offender Registration Act, 145 named after an eleven-year-old boy abducted by an unidentified stranger. ${ }^{146}$ As these state and federal registration laws withstood court challenges, ${ }^{147}$ municipalities have returned to the topic of registration,

\footnotetext{
138 Id. at 65.

${ }^{139}$ Lambert v. California, 355 U.S. 225, 229-30 (1957).

$140 \mathrm{Id}$. at 229.

141 Abbott v. City of L.A., 349 P.2d 974, 979 (Cal. 1960).

142 State v. Ulesky, 252 A.2d 720, 722-23 (N.J. 1969).

143 Id. at 723.

144 Sample \& Evans, supra note 36, at 212-14.
}

145 Violent Crime Control and Law Enforcement Act of 1994, Pub. L. No. 103-322 $\$ 170101,108$ Stat. 1796 (codified at 42 U.S.C. $\$ \S 14071-14073$ ), repealed by Adam Walsh Child Protection and Safety Act of 2006, Pub. L. No. 109-248, 120 Stat. 587 (codified at 42 U.S.C. $\S 16911(2006))$.

146 Karen J. Terry \& Alissa R. Ackerman, A Brief History of Major Sex Offender Laws, in SEX OFFENDER LAWS, supra note 36 , at $65,79$.

${ }^{147}$ See, e.g., Conn. Dep't of Pub. Safety v. Doe, 538 U.S. 1, 6-7 (2003) (holding that Connecticut's registration and community notification law did not violate the due process 
enacting more-stringent sex offender registries or registries for individuals convicted of gun offenses.

Albuquerque has created its own municipal sex offender registry, which includes broader registration requirements in an effort to close "loopholes" in the state law. ${ }^{148}$ While New Mexico law limited registration requirements to individuals who were convicted or remained incarcerated on or after July 1, 1995, Albuquerque's ordinance applies to any adult convicted of a sex offense against a child after $1970 .{ }^{149}$ The ordinance allowed only sixty days for individuals convicted over three decades ago to register in person with the Albuquerque Police Department, with failure to register punishable as a misdemeanor. ${ }^{150}$ The registration ordinance was almost entirely justified on exclusionary grounds, designed to drive out a high-profile sex offender who had settled in the town and to make it difficult for others to live there. ${ }^{151}$ According to Mayor Martin Chavez, the ordinance was intended "to help make Albuquerque one of the least desirable locations in the country for sex offenders."152

Other municipalities have recently experimented with gun offender registration ordinances, which seek to address gun violence by monitoring highrisk offenders returning to their communities. Their express purpose is not to exclude these offenders, but to supervise and control the behavior that leads to gun violence. The ordinances are patterned, however, after sex offender registration laws and premised on the idea that such laws have led to effective enforcement and supervision for individuals convicted of sex offenses. ${ }^{153}$

New York City passed the first gun offender registration ordinance in 2006 as part of a package of bills intended to combat gun violence. ${ }^{154}$ The ordinance required that any individual convicted of certain gun offenses (such as unlawful possession of a firearm) would have to register with the New York City Police

rights of individuals required to register, because registration requirements were solely based on convictions which they had previously had an opportunity to contest).

${ }^{148}$ Chris Ramirez, Child Molesters Are Given Two Months To Register, AlBUQUERQUE J., Oct. 30, 2003, at D2.

${ }^{149}$ Lloyd Jojola, Mayor Warns Sexual Predators, AlBUQUERQUE J., Feb. 7, 2004, at E2.

${ }^{150}$ Id.; Ramirez, supra note 148.

${ }^{151}$ See Katie Burford, Rapist Left N.M. Saturday, AlbuQuerque J., Dec. 16, 2002, at A1; Richard Willing, Albuquerque's Targeting of Sex Offenders Challenged, USA TODAY, May 12, 2003, at A4.

${ }^{152}$ Lloyd Jojola, Tougher Sex-Offender Law “Goes Too Far," AlbuQuERQUE J., June 14,2003 , at A1.

${ }^{153}$ Frequently Asked Questions About Gun Offender Registries, MAYORS AGAINST ILLEGAL GUNS, http://www.mayorsagainstillegalguns.org/downloads/pdf/Balto-NYC_com bined_GORA_FAQ.pdf (last visited Mar. 20, 2014).

${ }^{154}$ Press Release, N.Y.C. Office of the Mayor, Mayor Bloomberg Signs Legislation To Combat Gun Violence in New York City (July 27, 2006), available at http://www.nyc.gov/ portal/site/nycgov/menuitem.c0935b9a57bb4ef3daf2fl c701 c789a0/index.jsp?pageID=mayor press_release \&cat $[\mathrm{D}=1194 \&$ doc_name $=$ http $\% 3 \mathrm{~A} \% 2 \mathrm{~F} \% 2 \mathrm{Fwww}$.nyc.gov\% $2 \mathrm{Fhtml} \% 2 \mathrm{Fom}$ $\% 2 \mathrm{Fhtml} \% 2 \mathrm{~F} 2006 \mathrm{~b} \% 2 \mathrm{Fpr} 266-06 . \mathrm{html} \& \mathrm{cc}=$ unused $1978 \& \mathrm{rc}=1194 \&$ ndi=1. 
Department for four years after conviction or release from incarceration. ${ }^{155}$ Inperson registration is required within forty-eight hours of release, as well as every six months for the required registration period, and within ten days of a change of address; failure to register is punishable as a misdemeanor offense. ${ }^{156}$ Similar ordinances were passed by Baltimore in 2007; by Washington, D.C., and Utica, New York, in 2009; and by Chicago and Suffolk County, New York, in 2010.157

As these ordinances have proliferated, they have become more expansive, imposing additional collateral consequences on individuals with criminal convictions. For example, while New York City's registry information is shared only among police agencies, Chicago's registry is available online, allowing the public to search by neighborhood and view pictures, names, qualifying offenses, and other information for the individuals required to register. ${ }^{158}$ Fueled by concerns that not enough individuals were registering, Chicago's city council recently expanded the number of gun-related offenses requiring registration. ${ }^{159}$

Municipal gun offender registries have withstood early legal challenges similar to those mounted against sex offender registration laws, with a Maryland appeals court upholding Baltimore's ordinance against claims that it was unconstitutionally vague, violated equal protection guarantees, and was preempted by state law. ${ }^{160}$ As with sex offender registration laws, these ordinances have begun to move from city councils to state legislatures: in April 2013, Connecticut became the first state to enact a dangerous weapons offender registry as part of a comprehensive gun-control package. ${ }^{161}$

\section{Exclusionary Zoning Ordinances}

As sex offender registration laws increasingly became the province of state and federal legislation, municipalities have turned to zoning-style restrictions on the movements or residences of individuals with criminal convictions. For example, most restrictions on where registered sex offenders may live are

${ }^{155}$ N.Y.C., N.Y., CODE $§ 10-604$ (2012).

156 Id. $\S 10-602$.

${ }^{157}$ DuKe CHEN, CONN. OfFICE OF Legislative RESEARCH, GUN OfFENDER REgistries IN OTHER CITIES (Apr. 6, 2011), available at http://www.cga.ct.gov/2011/rpt/2011-R-013 8.htm.

158 CLEARMAP Registered Gun Offenders, CHI. POLICE DEP'T, http://gis.chicagopo lice.org/CLEARMap_rgo/startPage.htm\# (last visited Feb. 9, 2014).

${ }^{159}$ Fran Spielman, City Council Casts "Wider Net," Expands Gun Offender Registry, CHI. Sun-Times, Mar. 13, 2013 (updated Apr. 15, 2013, 11:19 AM), http://www.suntimes.com/18826999-761/city-council-casts-wider-net-expands-gun-offen der-registry.html.

160 State v. Phillips, 63 A.3d 51, 68-76 (Md. Ct. Spec. App. 2013).

161 Act Concerning Gun Violence Prevention and Children's Safety, 2013 Conn. Pub. Act No. 13-3. 
passed and enforced on a municipal level. ${ }^{162}$ Some municipalities have gone even further in restricting the movement of individuals with criminal convictions, forbidding registered sex offenders from entering public libraries or designating "exclusion zones" prohibiting entry to individuals convicted of weapons or drug offenses. Municipalities have also experimented with creating zones that ban individuals arrested or convicted for other crimes, such as drug possession or prostitution.

Restrictions on housing, employment, and movement for registered sex offenders are very common among municipalities in the United States, ${ }^{163}$ imposing some of the harshest collateral consequences on a tiny ${ }^{164}$ but highly stigmatized segment of the population. These restrictions began at the state level in 1995, when Florida passed a law prohibiting registered sex offenders on probation for offenses involving minor victims from living within 1000 feet of schools, parks, day cares, playgrounds, and other places where children congregate. ${ }^{165}$

The first municipal residential restrictions for registered sex offenders were enacted as amendments to zoning codes. In 1999, Lakewood, Colorado, enacted the first ordinance prohibiting more than one individual registered as a sex offender from living in a residence. ${ }^{166}$ Soon after, city council members in nearby Aurora "fast-tracked" similar language, citing fears that sex offenders from neighboring communities would move to their town: "What I don't want is for other municipalities to pass laws like this and have them all come to Aurora," one city council member said. ${ }^{167}$ Within less than a year, at least eight neighboring towns and counties had passed similar amendments to their zoning codes. ${ }^{168}$

162 OfFICE OF JUSTICE PROGRAMS, U.S. DEP'T OF JUSTICE, SEX OFFENDER REGISTRATION AND NotifiCATION IN THE UNITED STATES: CURRENT CASE LAW AND ISSUES 9 (July 2012), available at http://www.ojp.usdoj.gov/smart/caselaw/handbook_july2012.pdf.

${ }^{163}$ Richard Tewksbury, Exile at Home: The Unintended Collateral Consequences of Sex Offender Residency Restrictions, 42 HARV. C.R.-C.L. L. REV. 531, 537 (2007) (estimating that "perhaps hundreds of local communities now have laws that restrict where [registered sex offenders] may live").

${ }^{164}$ As of December 2013, an estimated 769,402 individuals living in the United States and its territories were required to register as sex offenders, or about $0.25 \%$ of the country's population. NAT'L CTR. FOR MISSING \& EXPLOITED CHILDREN, REGISTERED SEX OFFENDERS iN THE UNITEd STATES AND ITS TERritories PER 100,000 POPUlATION (Dec. 6, 2013), available at $\mathrm{http} / / / \mathrm{www}$.missingkids.com/en_US/documents/Sex_Offenders_Map.pdf.

165 Jill Levenson, Sex Offender Residence Restrictions, in SEX OFFENDER LAWS, supra note 36 , at 267,268 .

166 Andrew Guy Jr., Aurora Limits Sex Offenders: Law Prevents Group Homes, DENVER Post, Oct. 12, 1999, at B2.

${ }^{167}$ Andrew Guy Jr., Housing Limits in Works: Aurora Looks To Curb Sex Offender Numbers, DENVER POST, Sept. 22, 1999, at B2.

${ }^{168}$ Karen Rouse, Group Homes at Issue in Douglas County: Commissioners To Vote on Sex-Offender Limits, DENVER POST, Sept. 2, 2000, at B8. 
In April 2003, Albuquerque enacted an ordinance that, in addition to creating a new city registry, ${ }^{169}$ created the first municipal residential buffer zone for individuals convicted of sex offenses, forbidding them from living within 1000 feet of a school. ${ }^{170}$ The ordinance was enjoined by a judge for procedural due process reasons, including that it would require property-owning offenders to relocate from their current homes, and the Albuquerque City Council quickly enacted a new ordinance in order to retain most of the restrictions while addressing the constitutional issues. ${ }^{171}$ The revised residency restriction, prohibiting offenders from newly occupying residences within 1000 feet of a school, was upheld by the New Mexico Court of Appeals. ${ }^{172}$

In June 2005, Miami Beach, Florida, enacted a municipal ordinance expanding residence restrictions to 2500 feet for individuals convicted of sex offenses, rather than the 1000 foot buffer zone mandated by state law. ${ }^{173}$ Municipal residential restrictions on sex offenders spread rapidly across the country. ${ }^{174}$ By 2007, at least 400 municipalities had enacted such restrictions. ${ }^{175}$ In north Texas, for example, about twenty different cities passed residency restriction ordinances in just over a year. ${ }^{176}$ In addition to expanding buffer zones for locations like schools and day cares, many cities enacted additional residential restrictions around areas frequented by children, such as libraries, skating rinks, churches, or sports fields. ${ }^{177}$ Some ordinances also prohibited residences near senior or elderly housing. ${ }^{178}$

Other municipalities have sought to build on the popularity of residential restrictions by prohibiting individuals convicted of sex offenses from "loitering" near schools or playgrounds and even denying them entry to public spaces such as parks or libraries. ${ }^{179}$ For instance, Stephenville, Texas, prohibits sex

${ }^{169}$ See supra Part III.B.1 for details on the Albuquerque registry.

170 See Willing, supra note 151.

${ }^{171}$ ACLU of N.M. v. City of Albuquerque, 137 P.3d 1215, 1220 (N.M. Ct. App. 2006).

$172 \mathrm{Id}$. at 1228 . The court did, however, void other portions of the ordinance, which required individuals convicted of non-sexually-motivated crimes to register, prohibited individuals required to register from being alone with any child other than their own child or grandchild, and required them to submit DNA samples and dental imprints to the Albuquerque Police Department. Id. at 1232.

173 Levenson, supra note 165 , at 270-71.

${ }^{174}$ See, e.g., Kelly M. Socia, The Implementation of County Residence Restrictions in New York, 18 PSYCHOL. PUB. POL'Y \& L. 206, 207 (2012); Yung, supra note 13, at 125-26.

175 SaNdra Norman-EAdY, Cal. OfFice of Legislative Research, SeX OfFENDERS' RESIDENCY RESTRICTIONS (May 23, 2007), available at http://www.cga.ct.gov/2007/rpt/20 07-R-0380.htm.

176 See Cassie Dallas, Comment, Not in My Backyard: The Implications of Sex Offender Residency Ordinances in Texas and Beyond, 41 TEX. TECH L. REV. 1235, 1269 (2009).

177 Broward CNTY. Fla. SeXual Offender \& SeXual Predator Residence Task FORCE, FINAL REPORT 10-11 (Aug. 25, 2009), available at http://www.ilvoices.com/media/4 $5 \mathrm{c} 256903 \mathrm{e} 19 \mathrm{clafffff} 8 \mathrm{~d} 31 \mathrm{ffffe} 41 \mathrm{e} . \mathrm{pdf}$.

178 See, e.g., Hillsborough COUNTY, Fla., CODE $\S \S 36-274$ to -285 (2013).

179 See Jennifer Ekblaw, Note, Not in My Library: An Examination of State and Local Bans on Sex Offenders from Public Libraries, 44 IND. L. REV. 919, 927-28 (2011). 
offenders whose offenses involved children from entering libraries, bowling alleys, movie theaters, and bike trails, or from loitering (defined as "standing [or] sitting idly") within 300 feet of those facilities. ${ }^{180}$ These ordinances often go far beyond the collateral consequences imposed by state laws; most bans of sex offenders from libraries, for example, are imposed at the municipal level. ${ }^{181}$

As with residency restrictions, exclusionary anti-loitering ordinances tend to have a "ripple effect" as surrounding towns seek to keep undesirable individuals from moving into their communities. For example, Orange County, California, enacted an ordinance in 2011 making it a misdemeanor for a registered sex offender to enter any county park where children regularly gather without written permission from the sheriff's office. ${ }^{182}$ At the urging of county officials, thirteen cities in Orange County enacted similar anti-loitering ordinances within a year. ${ }^{183}$

Alongside the rise of municipal exclusion zones for registered sex offenders, a handful of municipalities have experimented with exclusion zones for individuals arrested or convicted of other types of crimes as well. ${ }^{184}$ Some of these ordinances have been struck down on constitutional grounds, or repealed based on concerns about discriminatory enforcement. Nonetheless, municipalities continue to enact such ordinances, particularly those that target stigmatized populations such as prostitutes and the homeless.

Portland, Oregon, enacted the first drug exclusion zone ordinance in $1992,{ }^{185}$ and created similar prostitution exclusion zones in $1995 .{ }^{186}$ Cincinnati, Ohio, followed in 1996 with a drug exclusion ordinance patterned on Portland's. ${ }^{187}$ Drug and prostitution exclusion zone ordinances designate certain neighborhoods associated with higher incidences of arrests or activity associated with these crimes. Anyone arrested for a drug or prostitution offense within one of these zones is banned from all exclusion zones for ninety days after the arrest, and for a full year after conviction for the crime. ${ }^{188}$

180 Stephenville, Tex., Ordinance 2007-18 (2007).

181 Ekblaw, supra note 179, at 931.

182 ORANGE COUNTY, CAL., CODE $\S \S 3-18-1$ to -6 (2011).

183 Press Release, Orange Cnty. District Attorney, Orange County District Attorney Applauds Santa Ana for Expanding Law To Keep Registered Sex Offenders Out of City Parks and Playgrounds (May 22, 2012), available at http://www.orangecountyda.com/ home $/$ index .asp?page $=8 \&$ recordid $=3010$.

${ }^{184}$ See Peter M. Flanagan, Trespass-Zoning: Ensuring Neighborhoods a Safer Future by Excluding Those with a Criminal Past, 79 NOTRE DAME L. REV. 327, 331-34 (2003).

185 Stuart Tomlinson, Drug-Free Law Goes into Effect in 2 Zones, OrEGonian, Apr. 29, 1992 , at B5.

${ }^{186}$ Chastity Pratt, How Prostitute-Free Zones Make Streetwalkers Scram, OREGONIAN, Dec. 14,1995 , at 1 .

187 Flanagan, supra note 184 , at 331.

188 Johnson v. City of Cincinnati, 119 F. Supp. 2d 735, 736 (S.D. Ohio 2000). 
Unlike sex offender residence restrictions, these ordinances apply to individuals who have been arrested but not yet convicted. ${ }^{189}$ As a result, these exclusion zone ordinances include additional notice and hearing requirements. Excluded persons are served with notices explaining the exclusion zones and the right to appeal, and can appeal to the city in writing within five days of being served. ${ }^{190}$ Upon appeal, the city has the burden of showing by a preponderance of the evidence that the individual committed the offense. ${ }^{191}$ In addition, excluded persons can apply for a variance from the police chief or certain social service agencies for reasons including living or working in an exclusion zone, needing access to drug counseling or other social services, or other reasons related to their health, welfare, or well-being. ${ }^{192}$ Without a variance, however, failure to comply with an exclusion is punishable as a misdemeanor. 193

Drug and prostitution exclusion zone ordinances have been repeatedly challenged in court, with varying results: While Portland's ordinances have survived, Cincinnati's drug exclusion zone ordinance was struck down by both the Supreme Court of Ohio ${ }^{194}$ and the Sixth Circuit. ${ }^{195}$ Both the Supreme Court of Ohio and the Sixth Circuit held that Cincinnati's ordinance violated the Due Process Clause of the Fourteenth Amendment, on the grounds that it infringed on the liberty right to intrastate travel without being narrowly tailored enough to allow excluded individuals into the exclusion zone for innocent or socially beneficial purposes. 196 The Sixth Circuit also found that the ordinance violated the right to freedom of association, noting that it precluded one of the defendants from caring for her grandchildren and prevented the other from visiting his attorney. ${ }^{197}$ On the other hand, Portland's drug and prostitution exclusion zone ordinances have survived multiple court challenges. ${ }^{198}$ Courts have held that the ordinance does not violate double jeopardy protections, because the exclusions are narrowly tailored enough to provide for variances and thus are not punitive in nature. ${ }^{199}$ Portland's ordinance was also found not

${ }^{189}$ Cincinnati's ordinance was amended in 1999 to clarify that the ninety-day exclusion would end if charges were dismissed or not filed, or if the individual was acquitted. Id.

190 Id. at 737 .

191 Id.

192 Id.

193 Id. at 736.

${ }^{194}$ State v. Burnett, 755 N.E.2d 857, 868 (Ohio 2001).

195 Johnson v. City of Cincinnati, 310 F.3d 484, 506 (6th Cir. 2002).

196 Id. at 504; Burnett, 755 N.E.2d at 867.

197 Johnson, 310 F.3d at 505-06.

198 State v. Lhasawa, 55 P.3d 477, 479 (Or. 2002) (upholding prostitution exclusion zone ordinance against double jeopardy challenge); State v. James, 978 P.2d 415, 421-22 (Or. Ct. App. 1999) (finding that drug exclusion zone ordinance did not violate double jeopardy); State v. Johnson, 988 P.2d 913, 915 (Or. Ct. App. 1999) (finding that drug exclusion zone ordinance did not violate defendant's due process rights).

${ }^{199}$ Lhasawa, 55 P.3d at 484-85; James, 978 P.2d at 420. 
to violate procedural due process rights, because defendants were given notice of their right to appeal the exclusion. ${ }^{200}$

Despite surviving legal challenges, Portland's drug and prostitution exclusion zones were allowed to expire in 2007, after a report commissioned by the mayor's office found that African-Americans were banned from drug exclusion zones at significantly higher rates than whites and Latinos arrested for the same crimes. ${ }^{201}$ In 2010, however, Portland enacted a new exclusion zone ordinance, this time targeting individuals arrested for gun offenses. ${ }^{202}$

Even in the face of concerns about legal challenges and discriminatory enforcement, other cities have adopted similar exclusion zone ordinances focused on "undesirable" populations, particularly prostitution. In Portland, prostitution exclusion zones have proven less controversial than drug exclusion zones for several reasons: first, arrests in prostitution exclusion zones are less racially imbalanced than in drug exclusion zones (although women were arrested at higher rates); second, the prostitution exclusion zones are more narrowly drawn. ${ }^{203}$ Another potential explanation came from Portland's police chief, who speculated that the public viewed prostitutes even less sympathetically than drug users. ${ }^{204}$ A prostitution exclusion zone ordinance modeled on Portland's was enacted by Charlotte, North Carolina, in 2005. 205 Advocates in Atlanta pushing for a similar ordinance also cited their desire to restrict the movement of "undesirables."206 A handful of cities in Florida, including Sarasota and Fort Lauderdale, have also enacted prostitution exclusion zones banning individuals on probation for prostitution, rather than merely those arrested for the offense. ${ }^{207}$

Cities in Oregon have also experimented with exclusion zones that target another stigmatized population: the homeless. One exclusion zone ordinance was enacted by Salem, Oregon, in 1993, targeting a range of behaviors including drug possession, public littering, and unlawful graffiti; in 2007, the

200 Johnson, 988 P.2d at 915.

${ }^{201}$ Drug- and Prostitution-Free Zone Ordinances To Expire, BUS. J. (Portland, Or.), Sept. 26, 2007; Andy Dworkin, Drug-Free Zones End on Bias Issues, OrEgONIAN, Sept. 27, 2007 , at A1.

${ }^{202}$ Portland Laws Take Aim at "Hot Spot" Gun Areas, AssOCIATED PrESs, Dec. 11, 2010, available at $\mathrm{http}: / / \mathrm{www} . \mathrm{kgw} . \mathrm{com} /$ news/Portland-laws-take-aim-at-hot-spot-gun-areas111720954.html.

${ }^{203}$ Andy Dworkin, Prostitution Zone Enforcement Mostly Affected Whites, Women, OREGONIAN, Sept. 29, 2007, at B1.

204 Id.

${ }^{205}$ Charlotte, N.C., Code OF ORDINANCES $\S \S 15-253$ to -260 (2012); Richard Rubin, Anti-prostitution Zone OK'd: Offenders Arrested in Area off Wilkinson Boulevard Will Be Barred from Re-Entering, CHARLOTTE OBSERVER (N.C.), Mar. 1, 2005, at B1.

206 Jenny Jarvie, Hometown USA: Atlanta; For Old Crime, an Old Remedy: Banishment, L.A. TimES, Feb. 24, 2013, at A15.

${ }^{207}$ See Sandra L. Moser, Anti-prostitution Zones: Justifications for Abolition, $91 \mathrm{~J}$. CRIM. L. \& CRIMINOLOGY 1101, 1101-02 (2001). 
city expanded the ordinance further to specifically target prostitution. ${ }^{208}$ More recently, the City of Eugene enacted a "downtown public safety zone" ordinance in $2008^{209}$ after having enacted a prostitution exclusion ordinance similar to Portland's from 2000.210 Anyone arrested within the zone for offenses such as harassment, providing alcohol to a minor, or public urination or defecation could be excluded from the twenty-square-block downtown area for ninety days after arrest and one year after conviction. ${ }^{211}$ Despite complaints that police used the ordinance to unfairly exclude homeless persons from the city's downtown, the ordinance has been renewed multiple times by Eugene's City Council. 212

\section{The Impact of Registration and Exclusionary Zoning}

Registration and exclusionary zoning ordinances impose some of the harshest collateral consequences on individuals with criminal convictions; failure to comply carries at least a misdemeanor penalty, punished with fines or incarceration. Limited municipal registries may serve legitimate public safety purposes by assisting police in identifying and deterring the highest-risk offenders, but expansive registries with onerous requirements are often motivated more by a desire to exclude "undesirable" populations. In particular, registration requirements and other collateral consequences imposed on sex offenders remain popular even though research has found that they do not deter or identify individuals at higher risk of reoffending. ${ }^{213}$ Albuquerque's registry monitors individuals convicted of sex offenses over three decades ago, for instance, despite evidence that sex offenders' risk of reoffending declines the longer they have been out of prison. ${ }^{214}$

Going even further, exclusionary zoning ordinances that restrict the housing and movement of individuals required to register as sex offenders may

${ }^{208}$ SALEM, OR., CODE $\S \S 95.730$ to .770 (2012); Jillian Daley, "Crime-Free Zone" Would Target Salem Prostitution, STATESMaN J. (Salem, Or.), Feb. 26, 2007, at 1; Dennis Thompson Jr., Police Set Crime Prevention District To Eradicate Prostitution, STATESMAN J. (Salem, Or.), Sept. 23, 2007, at 1.

${ }^{209}$ Editorial, Downtown Needs Real Fix, Register-Guard (Eugene, Or.), Aug. 13, 2008, at A8.

210 EugEne, OR., ORDINANCE No. 20205 (2000).

${ }^{211}$ Editorial, supra note 209.

212 See, e.g., Shannon Finnell, Piercy Backs Exclusion Zone; CLDC To Sue, EugENE WKLY., Oct. 10, 2012; Jack Moran, City's Exclusion Zone Gets Another Public Airing, REGISTER-GUARD (Eugene, Or.), Dec. 11, 2011, at B15.

${ }^{213}$ See, e.g., Richard TeWKSBURY, Wesley G. Jennings \& KrISTEn Zgoba, Final REPORT ON SEX OFFENDERS: ReCIDIVISM AND COllateral CONSEQUenCes 1-3 (Nat'l Inst. of Justice, Grant \#2009-IJ-CX-0203, 2012) (unpublished report), available at https://www.n cjrs.gov/pdffiles $1 /$ nij/grants/238060.pdf.

214 See, e.g., OHIO OfFICE OF CRIMINAL JUSTICE SERVS., REPORT TO THE OHIO CRIMINAL SENTENCING COMMISSION: SEX OFFENDERS 14 (2006), available at http://www.public safety.ohio.gov/links/ocjs_SexOffenderReport.pdf. 
effectively banish them from the community. ${ }^{215}$ Many municipal residential buffer zone ordinances make it near-impossible to find a permissible residential location within a town's borders. 216 The effect of these restrictions is particularly harsh in urban areas, where the concentration of schools, parks, and day cares may preclude permissible housing in most areas. Miami's residential restrictions are notoriously so strict that many individuals must live underneath bridges in order to comply. ${ }^{217}$ When these ordinances force offenders to cluster within a small area, neighbors often complain and local governments take further action to banish sex offenders entirely. The City of Los Angeles, for example, has built "pocket parks" for the express purpose of driving out registered sex offenders from specific neighborhoods, based on the residency restrictions in state law. ${ }^{218}$ The City of Dyersville, Iowa, went even further in passing a 2005 ordinance expressly banning sex offenders from residing anywhere within the city limits. ${ }^{219}$ After Iowa's governor signed a new state law in 2009 intended to void local sex offender residence restrictions, Dyersville's City Council decided to keep the law on the books even as the City Attorney acknowledged that failure to repeal it would invite a court challenge. 220

Exclusionary zoning ordinances may actually harm public safety by isolating individuals far from the services that allow them to avoid reoffending. For example, the City of Northglenn, Colorado, amended its zoning code to eliminate group homes for individuals convicted of registerable sex offenses, even though no reported harm had come from these houses and there was no evidence that such living arrangements increased recidivism. ${ }^{221}$ In 2003, the Colorado Supreme Court invalidated Northglenn's ordinance as applied to foster youth who had been adjudicated for sex offenses, on the grounds that the

215 See Logan, supra note 134, at 19.

216 See, e.g., Caitlin J. Monjeau, Note, All Politics Is Local: State Preemption and Municipal Sex Offender Residency Restrictions in New York State, 91 B.U. L. REV. 1569, 1578 (2011); Tewksbury, supra note 163, at 537-38.

217 Jenny Roberts, Ignorance Is Effectively Bliss: Collateral Consequences, Silence, and Misinformation in the Guilty-Plea Process, 95 IOWA L. REV. 119, 128 n.30 (2009) (citing Sex Offenders Living Under Miami Bridge, N.Y. TIMES, Apr. 8, 2007, at A22 (describing how local laws restricting where convicted sex offenders may live forced five men to live under a bridge and how they "must stay at the bridge from $10 \mathrm{p} . \mathrm{m}$. to $6 \mathrm{a} . \mathrm{m}$. because a parole officer checks on them nearly every night")).

${ }^{218}$ Ian Lovett, Neighborhoods Seek To Banish Sex Offenders by Building Parks, N.Y. TIMES, Mar. 10, 2013, at A22.

219 Dyersville, IOWA, CODE OF ORDINANCES ch. 49, §3 (2005), available at http://www.cityofdyersville.com/CityAdServ/Ordinances/Chapter49.pdf ("A sex offender shall not reside within the corporate City limits of Dyersville.").

${ }^{220}$ Michael Schmidt, Bid To Repeal Dyersville Ordinance Dies, TELEGRAPH HERALD (Dubuque, Iowa), Jan. 19, 2010, at A3.

${ }^{221}$ NORTHGLENN, COLO., ZONING CODE $\S 11-5-2(\mathrm{~b})(58)$ (2012), available at http://www.northglenn.org/municode/ch11/content_11-5.html; see Editorial, Housing Sex Offenders, DENVER POST, Feb. 20, 2000, at H4; Susan Besze Wallace, Fear Fuels Bans on Sex-Crime Group Homes, DENVER POST, Jan. 23, 2000, at Al. 
ordinance was preempted by state statutes governing mandatory placement and supervision for adjudicated delinquent youth in foster care. ${ }^{222}$ The ordinance remains on the books for adult offenders, however, with the ruling offering relief to only about 100 youths throughout the state. ${ }^{223}$ Other Colorado communities have retained similar ordinances, despite findings by the Colorado Sex Offender Management Board that these shared living arrangements could actually help reduce recidivism for higher-risk adult sex offenders, and that residency restrictions could be counterproductive by forcing individuals to live in remote areas far from safe support systems. ${ }^{224}$

Even though exclusionary zoning ordinances seriously curtail individuals' abilities to live and travel in their communities, there is little information available-even within counties-about which restrictions apply. For example, California's Proposition 83 enacted highly restrictive 2000-foot buffer zones for sex offenders' residences in 2006, and also offered express permission for local jurisdictions to enact even more restrictive ordinances. 225 As a result, within Los Angeles County alone at least thirty-seven different local ordinances have been enacted, all with different requirements. ${ }^{226}$ A California Sex Offender Management Board report identified at least eighty-seven separate city or county ordinances across the state, and concluded that "no one really seems to have an authoritative picture of how many such ordinances there are, what they say, who they apply to or to what extent they are enforced."227

The patchwork of overly restrictive local laws means that law enforcement may neglect to enforce them consistently, leaving individuals with criminal convictions in legal limbo. For example, officials in some Pennsylvania towns stated they had "forgotten the laws were on the books" after passing sex offender registry restrictions, and only learned about the restrictions after a state court ruling struck them down. ${ }^{228}$

${ }^{222}$ City of Northglenn v. Ibarra, 62 P.3d 151, 156-57 (Colo. 2003).

223 Editorial, Court Rejects NIMBY Laws, DENVER POST, Jan. 15, 2003, at B6.

${ }^{224}$ See Colo. Dep't of Pub. Safety, SEX OfFEnder MGMt. BD., RePORT ON SAFETY ISSUES RAISED BY LIVING ARRANGEMENTS FOR AND LOCATION OF SEX OFFENDERS IN THE COMMUNITY 3-5 (2004), available at http://dcj.state.co.us/odvsom/sex_offender/SO_Pdfs/

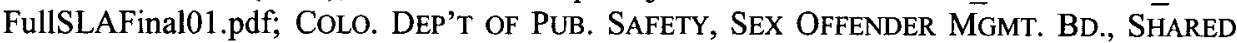
LIVING ARRANGEMENTS (SLAS) FACT SHEET 3 (2010), available at http://dcj.state.co.us/ odvsom/sex_offender/SO_Pdfs/SLA\%20Fact\%20Sheet.pdf.

${ }^{225}$ CAL. PENAL CODE $\$ 3003.5$ (West 2006). The statewide residential buffer zone has been stayed in San Diego as a blanket requirement, based on an appellate court finding that it essentially bans parolees from the county even if their crimes did not affect children. In re Taylor, 147 Cal. Rptr. 3d 64, 82-83 (Cal. Ct. App. 2012), review granted, 290 P.3d 1171, 1171 (Cal. 2013).

${ }^{226}$ CAL. SEX OFFENDER MGMT. BD., HOMELESSNESS AMONG CALIFORNIA's REGISTERED SEX OFFENDERS: AN UPDATE 8 (2011), available at http://www.casomb.org/docs/Residen ce_Paper_Final.pdf.

227 Id.

${ }^{228}$ Bill Reed, Ruling Has Towns Easing Megan's Laws, PHILA. INQUIRER, Oct. 3, 2011, at B1; see infra Part IV.A.1. 
In some cases, these ordinances have been voided as unconstitutionally vague $^{229}$ or as preempted by state laws governing the registration, residence, and movement of registered sex offenders. ${ }^{230}$ In others, however, these local ordinances have been upheld as a valid exercise of police power: In North Carolina, for example, an appeals court rejected a challenge to a town ordinance prohibiting any registered sex offender from knowingly entering a public town park. $^{231}$ In addition, court decisions voiding ordinances on constitutional grounds rarely prompt other communities to repeal similar ordinances. For example, the City of Albuquerque's ordinance banning registered sex offenders from libraries was voided by the Tenth Circuit as violating the plaintiff's First Amendment right to receive information in a public forum. ${ }^{232}$ Nonetheless, city officials in several Massachusetts cities argued that their local ordinances banning sex offenders from libraries could withstand a potential lawsuit because they were more narrowly tailored than the Albuquerque ordinance. ${ }^{233}$

\section{Municipal Background Check Policies}

One type of municipal collateral consequence that has recently received considerable attention, from scholars as well as from policymakers, has been the exclusion of individuals with criminal records from government employment. ${ }^{234}$ Many municipalities impose statutory or regulatory barriers on employment for individuals with criminal records. ${ }^{235}$ Municipal background check policies may include extensive inquiries into an applicant's arrest and conviction record for law enforcement jobs and other positions of public trust; ${ }^{236}$ bans on convictions for certain specific crimes in positions involving

${ }^{229}$ See, e.g., Elwell v. Twp. of Lower, CPM-L-651-05, 2006 WL 3797974, at *18-*19 (N.J. Super. Ct. Law Div. Dec. 22, 2006).

${ }^{230}$ See, e.g., People v. Oberlander, No. 02-354, 2009 WL 415558, at *4 (N.Y. Sup. Ct. Jan. 22, 2009).

${ }^{231}$ Standley v. Town of Woodfin, 650 S.E.2d 618, 623 (N.C. Ct. App. 2007).

${ }^{232}$ Doe v. City of Albuquerque, 667 F.3d 1111, 1117 (10th Cir. 2012).

${ }^{233}$ Ruling Could Affect Restrictions on Sex Offender Use of Mass. Libraries, WBUR Bos. (Jan. 31, 2012), http://radioboston.wbur.org/2012/01/31/sex-offenders.

${ }^{234}$ See, e.g., Jessica S. Henry \& James B. Jacobs, Ban the Box To Promote Ex-offender Employment, 6 CRIMINOLOGY \& PUB. POL'Y 755, 758 (2007); Michael Sweig \& Melissa McClure, "Moving the Box" by Executive Order in Illinois, 4 DEPAUL J. FOR SOC. JUST. 17, 35-38 (2010); see also LOVE ET AL., supra note 24, at 367-68.

235 See laura E. Johnson \& Renata CobBs Fletcher with Chelsea Farley, Public/Private Ventures, From Options to ACtion: A RoAdmap for City Leaders To CONNECT FORMERLY INCARCERATED INDIVIDUALS TO WORK 34 (2008) (arguing that cities and states impose "many statutory and regulatory disqualifications from forms of employment that have no relationship to the types of crimes committed" and suggesting that "depending on which local industries have opportunities, cities might want to focus on an inventory of legal barriers in construction, airport work, hospitality or health care").

236 See, e.g., Clinkscale v. City of Phila., No. Civ.A. 97-2165, 1998 WL 372138, at *2 (E.D. Pa. June 16, 1998) (justifying applicant's rejection from the Philadelphia Police Academy based on prior arrests, even though they did not result in a conviction and were 
financial transactions or classified records, ${ }^{237}$ broad prohibitions on hiring or retaining those convicted of crimes of moral turpitude; ${ }^{238}$ as well as more general background check requirements for most or all jobs. ${ }^{239}$ This Section will discuss the impact of collateral consequences in municipal employment, as well as legal challenges and recent municipal legislative reforms.

\section{Background Check Policies in Municipal Employment}

Criminal background checks are a common part of the municipal hiring process. ${ }^{240}$ A 2001 survey of municipal employers found that all of them conducted criminal background checks in hiring public-safety-related personnel (such as police officers and firefighters), and half conducted such checks on all prospective hires regardless of position. ${ }^{241}$ Heightened security concerns after 9/11 led even more employers to institute background checks. ${ }^{242}$ In addition, the trend towards centralizing and automating federal, state, and local court records databases and making them available online has made it easier for

later expunged, on the grounds that a police officer is granted "almost unlimited authority over his or her fellow citizens" and thus that "[e]ven an unjustified arrest may be indicative of character traits that would be undesirable in a police officer, such as a quick temper, poor attitude or argumentativeness"); Del Rivero v. Cahill, 390 N.E.2d 355, 360 (Ill. App. Ct. 1979) (affirming City of Chicago's exclusion of applicant convicted of driving under the influence from employment as a police officer based on the job's "peculiar and unusual position of public trust and responsibility").

${ }^{237}$ See, e.g., Mary L. Connerley et al., Criminal Background Checks for Prospective and Current Employees: Current Practices Among Municipal Agencies, 30 PUB. PERSONNEL MGMT. 173, 175 (2001).

238 See, e.g., United States v. City of Miami, Fla., 614 F.2d 1322, 1342, 1345-46 (5th Cir. 1980) (upholding a consent decree adopted by the City of Miami allowing the rejection of applicants for police officer positions who have been convicted of crimes involving "moral turpitude"); Fortman v. Aurora Civil Serv. Comm'n, 346 N.E.2d 20, 21-22 (Ill. App. Ct. 1976) (affirming decision to discharge a city sanitation employee on the basis of his conviction for unlawful delivery of a controlled substance, as a "criminal offense involving moral turpitude"); Shupe v. Warren Cnty. Sch. Bd., No. 99-165, 2000 WL 33340625, at *2 (Va. Cir. Ct. Mar. 31, 2000) (discussing school board employment application asking about prior convictions of violation of law and offenses involving moral turpitude).

${ }^{239}$ Connerley et al., supra note 237.

${ }^{240}$ SOC'Y FOR HuMAN RES. MGMT., SURVEY FINDINGS: BACKGROUND CHECKING-THE Use of Criminal BaCKGround CheCKS IN HiRING DeCisions 3 (2012). The poll of 544 randomly selected human resources professionals from the government sector, for-profit organizations, and non-profit organizations found that $69 \%$ conduct criminal background checks on all job candidates, $18 \%$ conduct such checks on select job candidates, and $14 \%$ do not conduct such checks on any job candidates. $I d$.

${ }^{241}$ Connerley et al., supra note 237 . Many municipal agencies that did not conduct background checks on all employees nonetheless reported conducting background checks on positions with responsibilities of a sensitive, confidential, or fiduciary nature.

242 See SEARCH, NAT'L CONSORTIUM FOR JUSTICE INFO. \& STATISTICS, REPORT OF THE National Task Force on the COMmerclal Sale of Criminal Justice Record INFORMATION 1 (2005); LOVE ET AL., supra note 24, at 56. 
governments - and often members of the public - to view individuals' records of arrests and convictions within seconds. ${ }^{243}$

Federal Title VII caselaw and Equal Employment Opportunity Commission (EEOC) guidance prohibit employers from imposing blanket exclusions on prior arrests or convictions where such policies impose a disparate impact on African-American and Hispanic applicants. ${ }^{244}$ Individuals with criminal records are not themselves considered a suspect class, but courts have on occasion applied the rational-basis test to invalidate state or municipal bans on hiring anyone with a prior felony conviction. ${ }^{245}$ For example, one such blanket ban imposed by the city charter of Alameda, California was struck down by a district court on the grounds that there could be no rational basis for a policy that failed to take into account length of time since a conviction occurred, the number of convictions, or the nature of the conviction and its relationship to the type of job sought. ${ }^{246}$

Across-the-board state and municipal bans on employing individuals with prior convictions have also been struck down on substantive due process grounds. In the above-mentioned case, the court also held that the challenged provision of the Alameda city charter denied the plaintiff substantive due process, in that it impaired his liberty interest in continued employment without a rational or nonarbitrary justification for doing so. ${ }^{247}$

While across-the-board bans are discouraged, employers may inquire into and consider those convictions that are "job related and consistent with business necessity." 248 In recent decades, federal courts have been reluctant to invalidate employment policies that consider arrest or conviction records, even when presented with broad policies justified through nebulous references to public safety or employee morale. ${ }^{249}$ Legal challenges to municipal agencies' criminal background check policies are rare, and even more rarely prove successful. ${ }^{250}$

243 Jacobs \& Crepet, supra note 41, at 183-84; see Anil Kalhan, Immigration Policing and Federalism Through the Lens of Technology, Surveillance, and Privacy, 74 OHIO ST. L.J. 1105, 1141-47 (2013).

${ }^{244}$ EEOC, supra note 11 , at 8-10; see also id. at n.90 (citing Green v. Mo. Pac. R.R., 549 F.2d 1158, 1160 (8th Cir. 1977)).

${ }^{245}$ See Kindem v. City of Alameda, 502 F. Supp. 1108, 1110-11 (N.D. Cal. 1980); Butts v. Nichols, 381 F. Supp. 573, 579 (S.D. Iowa 1974).

246 Kindem, 502 F. Supp. at $1111-13$.

247 Id. at 1113-14.

248 EEOC, supra note 11 , at 14.

${ }^{249}$ Alexandra Harwin, Title VII Challenges to Employment Discrimination Against Minority Men with Criminal Records, 14 BERKELEY J. AFR.-AM. L. \& POL'Y 2, 12-13 (2012).

${ }^{250}$ Connerley et al., supra note 237 , at 177 . The survey of municipal agencies found that $84 \%$ of responding agencies indicated that their criminal background check policies had not been legally challenged; the $8 \%$ of agencies that had faced a challenge said that they had successfully defended any complaints in court or from human rights agencies. 


\section{The Impact of Municipal Background Check Policies and Legislative Reforms}

The effects of denying or discouraging individuals with criminal convictions from municipal employment are significant: At least one in ten people employed in the United States works for local government. ${ }^{251}$ While many municipal jobs may involve public safety or positions of trust, such as police officers or teachers, others-such as janitorial or office work positionsshould be open to qualified individuals as long as their criminal convictions are not job related. ${ }^{252}$ Studies show that gainful employment helps reduce recidivism among individuals released from incarceration, suggesting that governments should encourage employment of such qualified individuals. 253

As cities have begun to recognize the need to ease the reentry of individuals returning from incarceration, many have focused on changing employment policies that impose barriers on individuals with criminal convictions. ${ }^{254} \mathrm{~A}$ handful of cities have sought to remedy the situation by enacting antidiscrimination ordinances that limit the ways in which local government agencies and other employers may consider an applicant's past arrest or conviction record in making an employment decision. ${ }^{255}$

A more popular approach for cities over the last decade has been to enact "Ban the Box" ordinances and policies, which reduce barriers to municipal

${ }^{251}$ The Employment Situation-January 2014, BuREAU LAB. STAT., at tbl. A-1, tbl. B-2 (Feb. 7, 2014), http://www.bls.gov/news.release/pdf/empsit.pdf (showing that of the 144 million people employed in the United States, about fourteen million of them are employed by local government).

252 While over half of local government employment is in education, this figure includes administrative and other personnel working within the school system. 2011 Public Employment and Payroll Data: Local Governments, U.S. CENSUS BUREAU, http://www2.cen sus.gov/govs/apes/11locus.txt (revised May 2013); see also Current Employee Statistics Frequently Asked Questions, BUREAU LAB. STAT., http://www.bls.gov/ces/cesfaq.htm (last updated Feb. 1, 2013).

${ }^{253}$ See, e.g., Mark T. Berg \& Beth M. Huebner, Reentry and the Ties that Bind: An Examination of Social Ties, Employment, and Recidivism, 28 JUST. Q. 382, 387-89 (2011); Christy A. Visher \& SHANNON M.E. COURTNEY, URBan INST., ONE Year OUT: EXPERIENCES OF PRISONERS RETURNING TO CLEVELAND 10-11 (2007), available at http://www.urban.org/UploadedPDF/311445 One_Year.pdf; see also Stephen J. Tripodi, Johnny S. Kim \& Kimberly Bender, Is Employment Associated with Reduced Recidivism?: The Complex Relationship Between Employment and Crime, 54 INT'L J. OFFENDER THERAPY \& COMP. CRIMINOLOGY 706, 713-15 (2010) (finding that individuals who obtained employment when released from prison were out significantly longer before recidivating than individuals who did not obtain employment).

${ }^{254}$ U.S. CONFERENCE OF MAYORS, Status OF EX-OFFENDER REENTRY EFForTS IN CITIES: A 79-CITY SURVEY 5 (2009), available at http://usmayors.org/pressreleases/uploads/ REENTRYREPORT09.pdf.

${ }^{255}$ See, e.g., MADISON, WIS., CODE $\$ 39.03$ (2013). Anti-discrimination ordinances, which often apply to private employers as well, will be discussed in more depth in Part III.D. 
employment for individuals with criminal convictions. ${ }^{256}$ Boston enacted the first "Ban the Box" ordinance in 2004. ${ }^{257}$ By April 2013, similar ordinances had been adopted by forty-three cities and counties-including municipalities as large as Seattle, Washington and as small as Cumberland County, North Carolina-and had spread to seven states. 258 "Ban the Box" ordinances, which require the removal of the "box" or question about past criminal records from initial employment applications, are intended to level the playing field by allowing applicants to be evaluated first based on their credentials without regard for criminal history. ${ }^{259}$ Criminal background checks may be conducted later in the process once an applicant has been deemed qualified for the job, at the interview or preliminary job offer stage. 260

\section{D. "Third-Party" Collateral Consequences}

Some municipalities have enacted ordinances that pass the enforcement of collateral consequences on to third parties, such as private employers or landlords, by encouraging or requiring the rejection of individuals with criminal convictions. Some of these barriers, such as requiring hotels that rent to sex offenders to obtain an additional license from the county, seem straightforwardly motivated by a desire to exclude certain "undesirable" populations from local communities. Broader background check policies can serve important public-safety purposes but in practice may lead to blanket rejections of anyone with an arrest or conviction record if they fail to include responsible guidelines empowering decision-makers to distinguish between relevant and irrelevant arrests or convictions.

At the same time, some municipalities have sought to reduce barriers imposed by private employers and landlords by extending "Ban the Box" or anti-discrimination ordinances. While municipalities without home rule powers may not be able to regulate private employers and landlords without state enabling legislation, they may draw on traditional municipal police powers to enact regulations tied to city contracts or licenses instead. This Section will discuss municipal ordinances that require private landlords and employers to conduct background checks or impose collateral consequences, as well as ordinances that seek to prevent these barriers.

256 LOVE ET AL., supra note 24, at 367-68.

${ }^{257}$ NAT'L EMP'T LAW PROJECT, BAN THE BOX: MAJOR U.S. CITIES AND COUNTIES

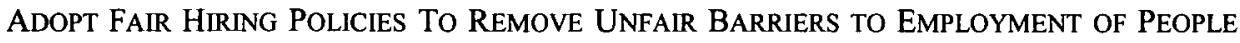
WITH CRIMINAL RECORDS 3 (2013), available at http://nelp.3cdn.net/495bf1d813cadb030d_q xm6b9zbt.pdf.

258 Id. at 1-2.

${ }^{259}$ Sweig \& McClure, supra note 234 , at 23-24.

${ }^{260}$ LOVE ET AL., supra note 24 , at 369. 


\section{Landlord Background Checks}

A number of municipalities have placed restrictions on private landlords' ability to rent to individuals with certain criminal convictions. Most ordinances target individuals convicted of sex offenses, while others include more general background check requirements through "good landlord" programs.

In an effort to make it as difficult as possible for registered sex offenders to reside in their communities, some municipalities have enlisted landlords and property managers to enforce their residency restrictions. Several municipalities have enacted ordinances making it a misdemeanor for landlords to rent residences to sex offenders that would run afoul of the residency restrictions. ${ }^{261}$ For example, Hillsborough County, Florida, prohibits more than one unrelated sex offender from living in a single residence, and further holds private landlords, real estate agents, or apartment complex managers accountable for enforcement by prohibiting them from having an unlawful number of sex offenders residing on any property they control. 262

Other municipalities have targeted hotels and motels, as strict residency restrictions have forced individuals convicted of sex offenses to move to transient housing. Because of the scarcity of legally permissible housing, as well as the stigma of sex offenses, sex offenders often cluster in the rare hotel or motel where managers are willing to rent to them. ${ }^{263}$ As a result, after New York courts voided several counties' sex offender residence restriction ordinances in 2009 on the grounds that they were preempted by state law, ${ }^{264}$ several towns and counties responded by requiring hotel and motel owners to pay for licenses if they rent rooms to sex offenders. ${ }^{265}$ Similarly, Riverside County, California, limits the number of rooms that a hotel or motel may rent to registered sex offenders to no more than six rooms or ten percent of the facility, whichever is less. ${ }^{266}$ The ordinance, which makes violations a misdemeanor offense, was passed on an emergency basis in order to block the state's plan to

261 See, e.g., RIVERSIDE COUNTY, CAL., CODE $\$ \$ 9.55 .010$ to .130 (2010).

262 Hillsborough COUNTY, Fla., CODE $\$ \S 36-304$ to -310 (2012).

263 See Sofia Santana \& Dana Williams, 24 Sex Offenders Lived at Budget Inn--Housing Dilemma, Sun-SENTINEL (Fort Lauderdale, Fla.), June 22, 2011 , at A1.

${ }^{264}$ See Doe v. Rensselaer Cnty., No. 223240, 2009 WL 2340873, at *3 (N.Y. Sup. Ct. June 29, 2009) (invalidating Rensselaer County sex offender buffer zone law as preempted by New York State law); People v. Oberlander, No. 02-354, 2009 WL 415558, at *4 (N.Y. Sup. Ct. Jan. 22, 2009) (invalidating Rockland County sex offender buffer zone law as preempted by New York state law); People v. Blair, 873 N.Y.S.2d 890, 892, 897 (Albany City Ct. 2009) (invalidating Albany County sex offender buffer zone law as preempted by New York state law).

265 See, e.g., QUEENSBURY, N.Y., CODE $\S \S 44-1$ to -20 (2013); see also SuFFOLK COUNTY, N.Y., CODE $\$ \S 745-16$ to -21 (2013) (requiring sex offenders to disclose their sex offender status when renting rooms in hotels or motels); Dave Lucas, NY Counties Enact Sex Offender Residency Laws, WAMC NoRTHEAST PUB. RADIO (Apr. 27, 2010, 2:46 PM), http://wamc.org/post/ny-counties-enact-sex-offender-residency-laws.

${ }^{266}$ RIVERSIDE COUNTY, CAL., CODE $§ 9.55 .060$ (c) (2010). 
release an individual convicted of a high-profile rape and murder into a group home in the community. ${ }^{267}$

In Utah, municipalities have enacted "good landlord" ordinances that charge fees to private landlords who do not conduct background checks or reject tenants with certain types of criminal convictions. ${ }^{268}$ These municipal ordinances were enabled by state law, which permitted municipalities to collect disproportionate rental fees if they established a "good landlord" program allowing landlords to avoid the higher fees provided they completed a training program and implemented "measures to reduce crime in rental housing."269 Most such municipal programs have required private landlords to reject individuals with certain types of criminal records. ${ }^{270}$ For example, the City of West Jordan requires landlords to reject any prospective tenant who "[w] ithin the past 3 years has been convicted of any drug or alcohol related crime, any crime related to theft or property damage, prostitution, lewdness, violence of any kind, assault, or crimes that involve weaponry of any kind" as well as registered sex offenders. ${ }^{271}$ Similarly, Ogden City's program requires participating landlords to conduct criminal background checks and to refuse to rent to any individual "convicted of any crime involving any threat or damage to property or person" within the previous four years. ${ }^{272}$ While the program is voluntary, landlords who do complete the training and agree to comply with the terms of the program receive a ninety percent fee reduction, potentially worth hundreds or thousands of dollars. ${ }^{273}$ Moreover, the city may revoke the "discount" if the police department reports that a landlord has failed to comply with program requirements, aided by a search of police or court records. ${ }^{274}$

Utah municipal leaders have been open about the exclusionary purposes served by "good landlord" ordinances. For example, the police department justified the West Jordan program in part by arguing that it "[d]iscourages the criminal element from residing in West Jordan."275 The executive director of the Utah Apartment Association, a key advocate in passing the state enabling legislation, stated that good landlord programs are "[a]bsolutely ... designed to

${ }^{267}$ Paul Young, County Clamps Down on Where Parolees Can Stay, CITY NEwS SERVICE (Southern Calif.), July 27, 2010.

${ }^{268}$ See Patrick B.N. Solomon, Utah's New Extermination Orders, 26 BYU J. PUB. L. 111,112 (2011).

${ }^{269}$ UTAH CODE ANN. § 10-1-203.5(1)(f)(i)(B)(ii) (West 2013).

270 Solomon, supra note 268 , at $119-21$.

${ }^{271}$ Id. at 121 (quoting Good Landlord Program, W. JoRDAN, http://www.wjordan.com/ Business.aspx?pglD=30.1 (last visited Feb. 7, 2014)).

${ }^{272}$ GoOd Landlord InCENTIVE Program, OGden CiTy, UTAH, § 1745-4, www.ogden city.com/en/sitecore/content/Global/Content/DocumentLinks/Business/Ordinance\%201745 $\% 20-\% 20$ Good\%20Landlord\%20Incentive\%20Program.aspx (last visited Mar. 20, 2014).

273 Solomon, supra note 268 , at 119.

274 Id. at $120-21$.

${ }^{275}$ Minutes of the City of West Jordan City Council Meeting 15 (Sept. 8, 2009), www.wjordan.com/Files/City\%20Clerk/2009\%20Minutes/September\%208,\%202009.pdf. 
discriminate against criminals ... [W]e reduce crime by not renting to criminals in the first place." 276

\section{Employer Background Checks}

Similar to ordinances governing private landlords, most municipal ordinances that discourage private employers from hiring individuals with criminal convictions specifically target individuals convicted of sex offenses. Palm Bay, Florida, has made it a misdemeanor for employers within the city limits to allow a registered sex offender whose offense involved a minor or vulnerable adult to work in facilities including school bus stops, libraries, parks, homes, or any "other place where children or vulnerable adults may reside or regularly congregate."277 Similarly, Albuquerque requires that these individuals must affirmatively notify their private employers of their sex offender status. ${ }^{278}$

Municipalities may also regulate the hiring practices of contractors to discourage the employment of individuals with prior convictions. Municipal ordinances commonly bar individuals with criminal records from applying for government contracts, ${ }^{279}$ and may also require that city contractors conduct background checks on their employees. ${ }^{280}$

\section{The Impact of "Third-Party" Collateral Consequences and Legislative Reforms}

Background-check policies of private landlords and employers can substantially impair the ability of individuals with criminal convictions to live and work within their communities. In turn, a lack of opportunities for housing and employment can have significant effects on public safety. Stable housing and employment have been shown to help reduce recidivism among individuals released from incarceration. 281 Recognizing these obstacles, some municipalities have enacted ordinances that prohibit discrimination by private landlords or employers on the basis of an applicant's arrest or conviction record.

${ }^{276}$ Ace Stryker, Cleanup or Shakedown: Provo Rental Ordinance Under Microscope, DAILY HERALD (Provo, Utah) (June 28, 2008, 11:00 PM), http://www.heraldextra.com/news/ local/cleanup-or-shakedown-provo-rental-ordinance-under-microscope/article_f $9 \mathrm{e} 26 \mathrm{c} 84$ 3dc9-5714-a320-03f07c3c1 f8c.html.

277 PALM BAY, FLA., CODE $\S \S 134.10$ to .12 (2005).

278 ALBUQUERQUE, N.M., CODE $\S \S 11-12-1-1$ to -6 (2013) (requiring probationary sex offenders to notify their employers of their offender status).

${ }^{279}$ LOVE ET AL., supra note 24, at 60 ; see, e.g., FoleY, ALA., CODE $§ 2-8$ (2013) (automatically disqualifying from contracting with the city any company owned or run by an individual convicted of a variety of felonies, including use or possession of a controlled substance).

280 See, e.g., AlBUQUerQUE, N.M., CODE $§ 11-12-2-7$ (2013) (requiring city contractors to conduct background searches of any employees "that may be alone with a child").

${ }^{281}$ NAT'L HOUSING LAW PROJECT, supra note 7, at 5; see also sources cited supra note 253. 
While anti-discrimination ordinances have not spread widely, the popularity of "Ban the Box" ordinances has encouraged some municipalities to extend their policies to private employers as well.

A handful of municipalities in Illinois and Wisconsin have enacted antidiscrimination ordinances that limit private landlords' ability to deny tenants on the basis of arrest or conviction records, with mixed results; the Wisconsin state legislature has curtailed such ordinances while the Illinois state legislature took affirmative steps to allow them.

Madison, Wisconsin, has long banned housing discrimination by public or private landlords against individuals on the basis of their arrest or conviction records, as part of an overall anti-discrimination ordinance designating individuals with arrest or conviction records as a protected class. ${ }^{282}$ Appleton, Wisconsin, has banned housing discrimination on the basis of arrest or conviction records as well. ${ }^{283}$ The county in which Madison is located, Dane County, also passed a fair housing ordinance prohibiting landlords from discriminating against tenants on the basis of an arrest or conviction record as long as the conviction is over two years old. ${ }^{284}$ These ordinances had a significant impact: From 2005 to 2010, the third most common type of fair housing complaint in Dane County was based on an arrest or conviction record. ${ }^{285}$ In 2011, however, the State of Wisconsin passed a law expressly prohibiting municipalities from placing limitations on landlords' ability to evaluate the arrest or conviction records of tenants or prospective tenants. ${ }^{286}$

In Illinois, two neighboring municipalities, Urbana ${ }^{287}$ and Champaign, 288 have ordinances prohibiting housing discrimination on the basis of arrest or conviction records. Like Madison's ordinance, both cities prohibit housing discrimination as part of an overall anti-discrimination ordinance that expressly protects individuals with arrest or conviction records. The ordinances also protect against discrimination in credit, access to public accommodations, and employment. ${ }^{289}$ Urbana's anti-discrimination ordinance, enacted in 1979, was initially held to be preempted by state laws where its protections went beyond those offered by the state. ${ }^{290}$ The Illinois state legislature quickly responded,

${ }^{282}$ MADISON, WIS., CODE $§ 39.03$ (2013).

283 APPLETON, WIS., CODE $\S 8-30$ (2012).

${ }^{284}$ DANE COUNTY, WIS., CODE $\S \S 31.01$ to 31.99 (2012); see also Matt DeFour, Dane County Tightens Housing Discrimination Ordinance, WIS. ST. J. (Sept. 3, 2009), http://host. madison.com/wsj/article_1bf94768-9908-11de-b7d3-001cc4c03286.html.

${ }^{285}$ MAXFIELD RESEARCH INC., ANALYSIS OF IMPEDIMENTS TO FAIR HOUSING CHOICE IN DANE COUNTY, WISCONSIN 81-82 (2010), available at http://pdf.countyofdane.com/human services/cdbg/2011/analysis_of_impediments_to_fair_housing_choice_2011_final.pdf.

${ }^{286}$ See WIS. STAT. $\S 66.0104$ (2011) (Act relating to prohibiting ordinances that place certain limits or requirements on landlords).

${ }^{287}$ URBANA, ILL., CODE $§ 12-37$ (2003).

288 ChAMPAigN, ILl., CODE $\S \S 17-2,17-71$ (1985).

${ }^{289}$ URBANA, ILL., CODE $§ 12-61$; ChAMPAIGN, ILL., CODE $\S \S 17-36,17-56,17-58$.

${ }^{290}$ Hutchcraft Van Serv., Inc. v. City of Urbana Human Relations Comm'n, 433 N.E.2d 329, 334 (IIl. App. Ct. 1982). 
however, by amending the law to expressly permit home rule cities (including Urbana and Champaign) to enact broader anti-discrimination policies than those under state law. ${ }^{291}$ Despite the encouragement of the Illinois state legislature, however, no new Illinois municipal ordinances have since been enacted to prohibit housing discrimination on the basis of arrest or conviction records. 292 In fact, Champaign limited its housing discrimination provisions in 1994 to allow landlords to reject individuals for forcible felony or drug convictions within the last five years. ${ }^{293}$

Municipalities seeking to reduce barriers faced by individuals with criminal records have had more success with ordinances that regulate private employers rather than private landlords. For example, Madison's anti-discrimination ordinance also prohibits employment discrimination on the basis of arrest or conviction records if the record is over three years old or the charge does not substantially relate to the circumstances of the job; the employment discrimination portions of the ordinance remain unchanged by state law. ${ }^{294}$ Similarly, Boston, Massachusetts, has banned employment discrimination on the basis of arrests without conviction and certain misdemeanor records. ${ }^{295}$ Urbana and Champaign, Illinois, both prohibit employment discrimination on the basis of arrest or conviction records except for when based on bona fide occupational qualifications. ${ }^{296}$

Much of the recent trend, however, has been for municipalities to encourage city contractors or private employers to hire individuals with criminal convictions through the extension of "Ban the Box" ordinances. At least eleven municipalities, including cities like New Haven, Connecticut, ${ }^{297}$ and Jacksonville, Florida, ${ }^{298}$ have enacted ordinances requiring city contractors to comply with "Ban the Box" guidelines mandating the removal of questions about arrest or conviction records from initial employment applications. ${ }^{299}$ Going further, Newark ${ }^{300}$ and Philadelphia ${ }^{301}$ have extended their ordinances requiring "Ban the Box" guidelines in hiring to apply to private employers operating within city limits as well. States have begun to follow the trend:

291 Page v. City of Chi., 701 N.E.2d 218, 226 (IIl. App. Ct. 1998).

292 See Local Anti-discrimination Ordinances, NAT'L HOUSING L. PROJECT, http://nhlp.org/node/1528 (last visited Feb. 7, 2014).

${ }^{293}$ Champaign, Ill., CODE $§ 17-75(\mathrm{e}) ;$ see Tom Pelton, Criminals Need Not Apply: Landlords Want To Know Tenants, CHI. TRIB., July 24, 1994.

294 MADISON, WIS., CODE $§ 39.03(8)(i)(3)$ (2013).

295 BOS., MASS., CODE $\S \S 12-9.1$ to .15 (2012).

${ }^{296}$ Urbana, IlL., CODE $\S \S 12-61$ to -62 (2012); Champaign, ILL., CODE $\S \S 17-36$ to -40

(2012).

${ }^{297}$ New HAVEN, CONN., CODE $\$ \S 2-851$ to -856 (2012).

298 JACKSONVILLE, FLA., CODE $§ 126.112$ (2011).

299 NAT'L EMP'T LAW PROJECT, supra note 257, at 1-2.

${ }^{300}$ Newark, N.J., Ordinance 12-1630 (Sept. 19, 2012).

301 PHILA., PA., CODE §§ 9-3501 to -3507 (2013). 
Minnesota recently expanded its "Ban the Box" law to cover private employers. ${ }^{302}$

\section{OPTIONS FOR REFORM}

The collateral consequences imposed by municipal ordinances can have devastating effects on individuals with criminal convictions, preventing them from working, living, moving freely, or participating in public life in their local communities. It may be particularly difficult for individuals facing criminal charges to obtain information about municipal collateral consequences, given that a person may live and work in multiple cities, towns, and counties within a single state. In addition, the variety of municipal collateral consequences can lead to a haphazard tangle of regulations within a single state. Exclusionary zoning ordinances, for example, may create a patchwork of impermissible areas that affected individuals find near-impossible to navigate. States can mitigate this issue by passing laws that clearly preempt or limit municipal powers to regulate in areas, such as sex offender residence registration, where municipalities have gone far beyond state law in attempting to banish these stigmatized populations.

At the same time, municipalities seeking to mitigate collateral consequences can lead the way for states in enacting modified portions of the UCCCA. As with "Ban the Box" ordinances, municipalities can serve as "proving grounds" for policies that set uniform standards and inform the public about local collateral consequences.

\section{A. State Law Reforms for Municipal Collateral Consequences}

Because cities derive their powers from states, one way for states to address the increasing patchwork of municipal collateral consequences is to preempt or limit municipal powers to regulate in this area. Municipal ordinances are frequently challenged as reaching beyond their state-granted powers or preempted by state law, as both state laws and municipal ordinances impose a wide variety of collateral consequences.

\section{Preemption}

Preemption is a common issue raised regarding collateral consequences imposed on the local level. If a local ordinance conflicts with a state law, or addresses an area where the state has already enacted a general law or a comprehensive set of regulations suggesting state supremacy on the matter, then the local ordinance is preempted by the state. ${ }^{303}$ On the other hand, if the local

3022013 Minn. Sess. Law Serv. Ch. 61 (West).

${ }^{303}$ SANDra M. STEVEnSON, ANTIEaU Local Government LaW $\S 22.05$ (Sandra M. Stevenson ed., 2d ed. 2005). 
ordinance complements the goals furthered by the state law, then the local ordinance may not be preempted even if it addresses the same matters as the state law. 304

When a municipal ordinance imposes collateral consequences in addition to those imposed by state law, then, the question is whether the additional sanctions imposed by the municipality conflict with or complement the state's sanctions. Courts must determine whether state legislators intended to impose a minimum set of sanctions on which municipalities could expand, or to delineate the entire permissible set of sanctions. For example, some courts have allowed municipalities to require licenses governing the same professions as states, even where the required licensing qualifications are more restrictive than state law, while others have interpreted state licensing regulations as preempting the entire field. ${ }^{305}$

Collateral consequences in licensing have also been challenged as preempted by state law, either because they go beyond those imposed by state law or on the grounds that they conflict with state anti-discrimination laws that set standards for when employment or licensing can be denied based on criminal records. For example, one court upheld the City of San Diego's authority to require pawnbrokers to obtain a local permit in addition to the state license required by California law. 306 The court voided sections of the ordinance that allowed the city to deny or revoke a local permit based on a single violation of state law, however, on the grounds that it conflicted with the state law allowing denial only if violations formed a pattern of conduct. ${ }^{307}$ Similarly, a Texas appellate court found that state anti-discrimination laws preempted a Dallas ordinance authorizing the denial of a taxicab driver's license for applicants with a theft conviction within the past five years. Because the state law only allowed for license denials when the criminal conviction was directly related to the duties and responsibilities of the licensed occupation, the court held that the city code could not impose a mandatory denial for theft convictions occurring within a specific time frame..$^{308}$

Preemption is also commonly raised in challenges of exclusionary zoning ordinances because most states, as well as many cities, have enacted laws restricting the housing and movement of sex offenders. Ever since some of the earliest municipal registration ordinances were struck down as preempted by state law, ${ }^{309}$ municipal registration and exclusionary zoning ordinances have been challenged on preemption grounds. Recent litigation over municipal sex offender residency restrictions has produced mixed results: courts in New

304 See id.

305 George D. Vaubel, Toward Principles of State Restraint upon the Exercise of Municipal Power in Home Rule, 24 STETSON L. REV. 417, 429-30 (1995).

306 Malish v. City of San Diego, 101 Cal. Rptr. 2d 18, 23 (Cal. Ct. App. 2000).

307 Id. at 22-27.

308 Johnson v. City of Dall., 702 S.W.2d 291, 292 (Tex. App. 1985).

${ }^{309}$ Abbott v. City of L.A., 349 P.2d 974, 982 (Cal. 1960); State v. Ulesky, 252 A.2d 720, 722-23 (N.J. 1969); see also supra Part III.B.1. 
York, ${ }^{310}$ New Jersey, ${ }^{311}$ Pennsylvania, ${ }^{312}$ and Colorado ${ }^{313}$ have invalidated such ordinances on the grounds of preemption, while courts in Florida ${ }^{314}$ have found that no conflict or preemption exists. Despite the many court challenges, municipalities have often declined to repeal sex-offender residency restrictions even in the face of state court rulings voiding similar ordinances. In such states, municipalities often split between repealing and leaving such ordinances on the books, ${ }^{315}$ leading to additional confusion about whether collateral consequences may apply in a given situation.

At least two states have taken affirmative measures to preempt the proliferation of municipal sex offender residency restrictions. New Mexico passed a state law in 2005 expressly preempting the field of sex offender registration and notification in order to keep local ordinances from proliferating, but it did allow existing local ordinances to remain in effect as long as they did not conflict with state law. ${ }^{316}$ More recently, the law was expanded to preempt municipalities from imposing additional restrictions on sex offenders, including requirements to register more frequently or to provide additional information to law enforcement. ${ }^{317}$ In 2009 , Iowa passed a state law that voided all local

310 See sources cited supra note 264; see also Moore v. Cnty. of Suffolk, 851 F. Supp. $2 d 447,457$ (E.D.N.Y. 2012) ("Every court that has considered the state preemption issue to date has found that New York State's legislative scheme concerning sex offenders preempts the local laws."); Terrance v. Geneva, 799 F. Supp. 2d 250, 257 (W.D.N.Y. 2011) (declaring Geneva sex offender buffer zone ordinance invalid on preemption grounds).

${ }^{311}$ G.H. v. Twp. of Galloway, 401 N.J. Super. 392, 407, 421 (Super. Ct. App. Div. 2008), aff'd, 199 N.J. 135, 136 (2009) (invalidating sex offender residential restriction ordinances in Galloway Township and Cherry Hill Township as preempted by New Jersey state law, in part because the exclusionary effects of the buffer zones interfered with state parole officers' mandate to find appropriate housing for offenders).

${ }^{312}$ Fross v. City. of Allegheny, 20 A.3d 1193, 1206-07 (Pa. 2010) (holding that Allegheny County's broad residential restrictions were contrary to the state scheme, which balanced more limited restrictions with "individually tailored assessments and assistance with rehabilitation and reintegration for appropriate offenders").

${ }^{313}$ City of Northglenn v. Ibarra, 62 P.3d 151, 156 (Colo. 2003) (holding that the City of Northglenn's ordinance, as it applied to prohibiting multiple children adjudicated as sex offenders from living in a single foster care home, was preempted by "[ $t]$ he state's interest in fulfilling its statutory obligations to place and supervise adjudicated delinquent children in foster care homes pursuant to uniform, statewide criteria").

${ }^{314}$ Exile v. Miami-Dade Cnty., 35 So. 3d 118, 119 (Fla. 2010); see also Calderon v. State, 93 So. 3d 439, 440-41 (Fla. Dist. Ct. App. 2012).

315 Compare Joyce M. Miles, Sex Offender Residency Limits Gone, LOCKPORT UNIONSuN \& J., Aug. 2, 2012 (discussing repeal of municipal ordinances in New York), with Reed, supra note 228, at B1 (quoting a lawyer with the American Civil Liberties Union of Pennsylvania: "In these kinds of cases, towns usually don't repeal their laws."), and Barbara Williams, Sex Offender Redlines Erased; Conforms to Supreme Court Ruling, Herald NEws (Passaic County, N.J.), Nov. 17, 2009, at B1 (noting that over 125 New Jersey communities had enacted sex offender residency restrictions, and that they "have split on repealing their local ordinances" since the Supreme Court ruling).

316 N.M. STAT. ANN. § 29-11 A-9 (2012).

${ }^{317}$ H.B. 570, 51 st Leg., Reg. Sess. (N.M. 2013) (effective date Jan. 1, 2014). 
ordinances restricting the residence or movement of registered sex offenders, ${ }^{318}$ even as it added new restrictions banning registered sex offenders from being present in schools, libraries, playgrounds, and other public areas. ${ }^{319}$

On the other hand, some states have passed laws that only encourage the patchwork of harsh municipal collateral consequences to spread. For example, California's Proposition 83 expressly allowed local jurisdictions to enact even more restrictive sex offender residency restrictions, leading to over eighty-seven separate city or county ordinances across the state. 320 Similarly, Ohio has enacted a statute expressly permitting local jurisdictions to pass sex offender residency ordinances that are more restrictive than state law. The City of Newark, Ohio, responded by passing an ordinance restricting sex offenders from living within 1000 feet of city parks and the municipal swimming pool, in addition to the buffer zones created by the state law. The ordinance proved so restrictive that in order to enforce it, the city's Law Director became "something of a real-estate agent for sex offenders," checking addresses weekly for about 100 individuals against a software mapping program to ensure compliance. ${ }^{321}$

\section{Limits of Municipal Power}

Because cities are creatures of state power, another way for states to reduce the patchwork of collateral consequences in a given regulatory area is to limit the power municipalities have to pass such regulations. Court challenges to municipal ordinances may address the question of whether the state has granted municipalities the power to regulate in this area at all. ${ }^{322}$ Courts have long held that local governments have the power to regulate businesses, occupations, and professions that make use of public property (such as roads, sidewalks, and parks) as well as those susceptible to causing nuisances or harm to public safety. ${ }^{323}$ On the other hand, states often limit the power of municipalities to impose penalties for violating an ordinance that go beyond those allowed in state statute. ${ }^{324}$ Where municipal ordinances impose collateral consequences enforced by penalties, such as exclusion zones or residential restrictions, they may extend beyond their state-granted powers.

For example, the Supreme Court of Ohio invalidated Cincinnati's drug exclusion zone ordinance based in part on its finding that the ordinance added a criminal penalty for drug offenses that was not imposed through sentencing or

318 IOWA CODE $\S 692 A .127$ (2010).

${ }^{319}$ Id. $\$ 692 \mathrm{~A} .113$.

${ }^{320}$ CALIF. SEX OFFENDER MGMT. BD., supra note 226, at 8.

${ }^{321}$ Mary Beth Lane, Sex-Offender Ghettos: Get-Tough Laws Force Predators To Move but Do Little To Make Kids Safer, ColumBus DisPaTCH, Oct. 7, 2007, at A10.

${ }^{322}$ See, e.g., City of Akron v. Williams, 177 N.E.2d 802, 805 (Ohio Ct. App. 1960) (finding that city had power to enact municipal ordinance prohibiting individual with felony record from possession of firearm).

323 See, e.g., Tarver v. City Comm'n of Bremerton, 435 P.2d 531, 535 (Wash. 1967).

324 See MCQULLIN, supra note 69, § 17:15. 
authorized by state statute. ${ }^{325}$ Similarly, the Texas Attorney General issued an opinion in 2007 finding that the state's home-rule municipalities had the authority to enact residential restrictions on registered sex offenders, but that general-law municipalities did not. ${ }^{326}$ Despite this opinion, many of the thirty general-law municipalities that already had these ordinances did not repeal them. ${ }^{327}$

\section{What States Can Do}

While numerous municipal ordinances that impose collateral consequences have been voided on the grounds that they are preempted or go beyond the powers granted in state law, states have rarely taken affirmative steps to eliminate the patchwork of harsh collateral consequences imposed by municipalities. As a result, state and local decision-makers may be unaware of the barriers posed by the tangle of regulations across the state, particularly for sex offender residency restrictions. ${ }^{328}$ With budgets ballooning from the costs of incarceration, however, some states have increasingly sought to lower reoffending rates among individuals released from incarceration through policies that reduce barriers to their successful reintegration. ${ }^{329}$

Some state legislatures have begun to address collateral consequences, passing "Ban the Box" laws as well as new laws that help individuals expunge old criminal records or seek relief from specific collateral consequences. ${ }^{330}$ Several states, including New York and Mississippi, have passed laws in recent years to expand eligibility to expunge or seal criminal records. ${ }^{331}$ In addition to North Carolina's partial passage of the UCCCA, Ohio passed a "collateral sanctions" law, which creates certificates of rehabilitation to assist individuals seeking relief from specific collateral consequences, and also changes the criminal background check requirements for licensing. ${ }^{332}$

State legislatures interested in mitigating unnecessary collateral consequences could repeal laws that allow municipalities to enact harsh ordinances such as those restricting where registered sex offenders can live, and enact laws explicitly preempting such ordinances instead. States can also

${ }^{325}$ State v. Burnett, 755 N.E.2d 857, 868 (Ohio 2001).

326 Tex. Att'y Gen. Op. No. GA-0526 (Mar. 6, 2007).

${ }^{327}$ Dallas, supra note 176, at 1266; see also LAWREN FORD CRAWFORD, TEX. MUN. LEAGUE LEGAL COUNSEL, LEGAL Q\&A 2 (June 2008), available at http://www.tml.org/legalqna/2008June-LFC.pdf.

328 CALIF. SEX OFFENDER MGMT. BD., supra note 226, at 8.

${ }^{329}$ See, e.g., Jason Chaffetz, Commentary, Getting Smart About Crime, WASH. TIMES, July 15, 2013; Steven Greenhouse, States Help Find Work (and Hope) for Ex-Convicts, N.Y. TIMES, Jan. 25, 2011, at B1.

${ }^{330}$ See supra Part III.C.2.

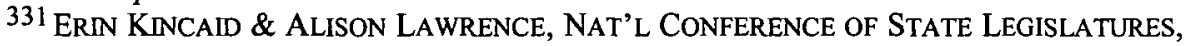
EX-OFFENDER EMPLOYMENT OPPORTUNITIES 3 (2011), available at http://www.ncsl.org/docu ments/cj/pew/ex-offenderreport.pdf.

${ }^{332}$ S.B. 337, 129th Gen. Assemb., Reg. Sess., 2012 Ohio Laws 131. 
preempt municipalities' blanket bans on criminal records in licensing and employment by passing laws setting standards for when these benefits may be denied on the basis of a relevant criminal record. When such laws clearly state an intent to preempt local action, they can mitigate collateral consequences imposed at the state as well as at the municipal level. For example, courts in some cities have overturned municipal policies mandating the denial of licenses for taxicabs or rooming houses based on criminal convictions, on the grounds that such policies conflict with state anti-discrimination laws. ${ }^{333}$

On the other hand, some states have preempted or limited municipal ordinances with state laws that create even harsher restrictions on individuals with criminal records. As noted above, Wisconsin enacted a law to preempt local ordinances prohibiting landlords from discriminating against tenants on the basis of arrest records. ${ }^{334}$ Advocates seeking state action to address municipal collateral consequences should begin, of course, by assessing the state's political climate. Moreover, advocates should survey municipal ordinances and policies within the state to ensure that state action will not simply impose harsher, albeit more uniform, collateral consequences across the state. These concerns may be particularly relevant for policies-such as exclusionary zones for sex offenders-that impact highly stigmatized populations.

\section{B. Using Municipal Ordinances To Address Collateral Consequences}

The impact of collateral consequences in municipal ordinances suggests a new avenue for advocates: using cities and counties as "proving grounds" 335 for laws that collect and provide relief from collateral consequences. Municipal collateral consequences ordinances will not only help to inform local residents, attorneys, and judges about relevant collateral sanctions; they can also help to build support for similar policies in other cities and at the state level.

The success of "Ban the Box" ordinances suggests that many municipalities recognize the barriers that collateral consequences pose for individuals with criminal convictions. Municipalities can build on "Ban the Box" ordinances by enacting ordinances that, as with municipal employment, outline the standards

${ }^{333}$ See, e.g., Standow v. City of Spokane, 564 P.2d 1145, 1152-53 (Wash. 1977) (overruled on other grounds by State v. Smith, 610 P.2d 869, 874 n.2 (Wash. 1980)); Marra v. City of White Plains, 467 N.Y.S.2d 865, 869-70 (N.Y. App. Div. 1983); see also Peluso v. Smith, 540 N.Y.S.2d 631, 636 (N.Y. Sup. Ct. 1989) (directing New York City's Department of Personnel to "hold a fact-finding evidentiary hearing ... to examine, apply and determine the applicability of the factors set forth" in New York's state law governing the use of criminal convictions in employment and licensing decisions before making a decision regarding the plaintiff's application for a site safety manager license).

334 WIS. STAT. $\$ 66.0104$ (2011).

335 Paul A. Diller, The Partly Fulfilled Promise of Home Rule in Oregon, 87 OR. L. REV. 939, 957 (2008) (quoting Sims v. Besaw's Cafe, 997 P.2d 201, 213 n.3 (Or. Ct. App. 2000) (Linder, J., concurring)). 
that must be met for imposing collateral consequences in areas such as licensing for an individual with a relevant criminal conviction. Such ordinances should also commit the municipality to collect and publish the collateral consequences in the municipal code, both for transparency in governmental decision-making and to better inform community members and their attorneys about the possible consequences they face. Collecting municipal collateral consequences is particularly important because-unlike at the state and federal level-there is no concerted effort already underway to research these issues. Compiling municipal collateral consequences may also build pressure to repeal those consequences that serve exclusionary rather than public safety purposes. In addition, municipalities that criminalize municipal ordinance violations should explore the potential for creating their own mechanisms for expunging municipal criminal records.

This Section will outline key issues for municipalities to consider in enacting collateral consequences policies, offering the example of the first municipal collateral consequences ordinance enacted in 2012 by New Haven, Connecticut. Inspired by the UCCCA, New Haven's collateral consequences ordinance sets standards for imposing collateral consequences and commits to collecting, publishing, and annually updating the collateral consequences found in the city's municipal code. Furthermore, this Section will argue that the success of "Ban the Box" policies helped to ensure the passage of New Haven's ordinance, and that advocates can build on these successes to pass similar collateral consequences ordinances in other cities.

\section{Municipal Standards for Imposing Collateral Consequences}

One of the most important purposes of a municipal collateral consequences policy is to set standards for when arrest or conviction records are considered relevant and when they are not. Municipalities have taken a variety of approaches in setting standards for linking collateral consequences to relevant criminal history, including offering more general guidelines as in the UCCCA; setting out factors to consider as in many "Ban the Box" ordinances; or protecting certain types of arrest or conviction records from consideration under anti-discrimination ordinances.

The UCCCA offers general guidelines for when governmental decisionmakers may consider a criminal record to be relevant. First, the UCCCA provides that when a law creating a collateral consequence is ambiguous as to whether it is mandatory or discretionary, it must be construed as discretionary. ${ }^{336}$ Second, the UCCCA requires that when the municipality imposes a discretionary collateral consequence, the decision-maker undertake an individualized assessment that considers any circumstances and elements of the offense relevant to the benefit or opportunity in question, as well as the effect of the decision on third parties and any certificates granting relief from

336 UNIF. COLlateral CONSEQUENCES OF CONVICTION ACT $§ 7$ (2010). 
the collateral consequence. ${ }^{337}$ New Haven's collateral consequences ordinance includes these general guidelines to be used in decision-making for all collateral consequences imposed by city government, as well as the specific "Ban the Box" factors for licensing.

"Ban the Box" ordinances, which mitigate collateral consequences relating to employment, often set specific standards by which public or private employers must weigh the relevance of an applicant's criminal record to the position sought. For example, the "Ban the Box" ordinances passed by Memphis and New Haven require that decision-makers consider several factors in making a determination about whether a prior conviction is relevant to a job: the nature of the crime and its relationship to the job; information about rehabilitation; the length of time elapsed; the applicant's age at the time of the offense; and the gravity of the offense. ${ }^{338}$ These factors offer a standard for responsible decision-making regarding an individual's criminal record for any collateral consequence, not simply employment. New Haven's collateral consequences ordinance provides the same factors for relevance in a criminal record for licensing purposes.

Another approach, illustrated by ordinances in Boston, Madison, Urbana, Champaign, and New York City, is to add arrest or conviction records to the list of protected classes in the municipal anti-discrimination ordinance. ${ }^{339}$ Because these ordinances generally allow discrimination based on arrest or conviction records in situations where the conviction is recent and/or relevant to the benefit or right in question, they may also delineate specific types of arrest or conviction records which may or may not be considered. For example, Boston prohibits employment discrimination on the basis of arrests without conviction, convictions for certain misdemeanors including simple assault or disturbing the peace, or misdemeanor convictions over five years old. ${ }^{340}$ One advantage of guidelines that specifically state lengths of time and types of convictions is that they provide clear instructions to decision-makers and are transparent for applicants. On the other hand, overly specific guidelines may hinder decisionmakers' ability to make nuanced judgments based on a variety of factors. For example, Boston's ordinance clearly protects a job applicant whose misdemeanor convictions are less than five years old, but not one whose record is just a few days more recent. Another drawback of specifying certain types of convictions is that they risk falling out of date with changes in state criminal laws, or providing uneven protection to individuals convicted of similar crimes in other states. While anti-discrimination ordinances have generally not listed factors for assessing relevance along the lines of "Ban the Box" policies, doing so might offer a more nuanced approach.

${ }^{337}$ Id. $\$ 8$.

338 MEMPHIS, TENN., CODE § 3-4-4 (2012); New HAVEN, CONN., CODE § 2-852 (2012).

339 See, e.g., N.Y.C., N.Y., ADMIN. CODE § 8-107; see also supra Part III.D on thirdparty collateral consequences.

340 BOS., MASS., CODE $\S \S 12-9.1$ to .15 (2012). 
One advantage of anti-discrimination ordinances may be their potential for broader scope: They may apply not only to government employers and licensing agencies, but to private employers and landlords as well. ${ }^{341}$ The emphasis on private entities, however, can draw focus from municipal decision-making. For example, Urbana's taxicab licensing ordinance, which disqualifies any applicant with a felony conviction from the previous four years, has been recently criticized as conflicting with the city's anti-discrimination ordinance. ${ }^{342}$ The advantage of enacting a more comprehensive collateral consequences ordinance is that it requires municipalities to examine governmental decision-making in a variety of arenas, including licensing as well as employment and housing. By providing clear guidelines for when municipalities may impose collateral consequences on individuals with criminal records, these ordinances offer a clear path for extension to private employers and landlords as well.

\section{Municipal Collection of Collateral Consequences}

The lack of scholarly attention to the issue of municipal collateral consequences reinforces the need for municipalities to offer transparent information to the public about what collateral consequences are imposed by their codes of ordinances. Unlike at the state or federal level, no comprehensive database of collateral consequences is being compiled at the municipal level. Therefore, it is particularly important that municipalities seeking to address the issue of collateral consequences commit to collecting, publishing, and updating the collateral consequences imposed in the municipal code.

While the UCCCA would require attorneys and judges to advise defendants about relevant collateral consequences, municipalities cannot impose duties on the state and federal court systems. Municipalities with city court systems could conceivably require city court judges to provide such information, assuming they had the power to do so under state law. In any case, Padilla and the ABA standards already direct attorneys to advise their clients about relevant likely consequences of a plea. Publishing municipal collateral consequences online will assist attorneys in fulfilling these obligations.

Even without court disclosure requirements, identifying municipal collateral consequences is the first step towards reforming them. These compilations may spur municipalities to reduce or eliminate collateral consequences that are outdated, little-enforced, or overly harsh. For example, many municipal restrictions on issuing licenses to individuals with criminal convictions may date back to the late nineteenth or early twentieth century. ${ }^{343}$ In developing New Haven's collateral consequences ordinance, advocates discovered that the city's code placed inconsistent standards on fingerprinting and criminal

${ }^{341}$ See supra Part III.D.

${ }^{342}$ Patrick Wade, Vehicle-for-Hire Ordinance's Felon Rule Piques Interest, NEWsGAZETTE (Champaign-Urbana, Ill.), May 15, 2013.

${ }^{343}$ See supra Part III.A. 
background checks for different licenses. As a result, the collateral consequences ordinance was modified to standardize the process by which an applicant's criminal background would be evaluated for all licenses. ${ }^{344}$ Collecting and publishing the full set of collateral consequences may also help influence municipal decision-makers to repeal overly harsh ordinances, such as sex offender residency restrictions, that are costly to enforce and defend in court.

While the effort of compiling a municipality's collateral consequences and publishing them online does require some resources, it is likely to be less costly than such an effort would be for state or federal laws and regulations. Municipal codes of ordinances tend to be shorter and more limited than state and federal laws. In addition, many municipal codes are now available in searchable form online, making it simpler to search for collateral consequences. ${ }^{345}$ Because this provision of the UCCCA has not yet been enacted by any state, municipalities are uniquely well-placed to demonstrate its feasibility by committing to compile and update their own collections of collateral consequences. Moreover, as increasing numbers of cities establish reentry programs or initiatives to reduce barriers for individuals returning to the community after incarceration, ${ }^{346}$ the collection of collateral consequences may be a natural responsibility for these programs. New Haven's collateral consequences ordinance, for example, assigns responsibility to the city's Reentry Initiative for publishing and updating the city's collection of collateral consequences. Limitations on resources may prevail, however; although New Haven's collateral consequences ordinance committed to publishing its compilation online by January 1, 2013, nothing had been published on the city's website as of January 22, 2014.347

\section{Municipal Expungement of Records}

The UCCCA also includes provisions relating to expunging criminal records or granting selective relief from their consequences. Municipalities create and maintain two types of criminal records giving rise to collateral consequences: First, police departments maintain and distribute information about arrest records; and second, municipal or county courts create and maintain conviction records for violations of municipal ordinances. However, municipalities have generally not enacted ordinances providing for individuals to seek expungement or sealing of these records. In general, state laws appear to have preempted this option by enacting relatively comprehensive schemes by which individuals may apply to limit access to their arrest and/or conviction records. For example, in People v. Valentine ${ }^{348}$ an Illinois appellate court held

${ }^{344}$ See deleted sections of NEW HAVEN, CONN., CODE $\S \S 17-4.4(a), 17-6.4$, available at http://nelp.3cdn.net/fc30756eea189d6676_lrm6bn7xd.pdf.

345 Diller, supra note 68 , at 1125 .

${ }^{346}$ U.S. CONFERENCE OF MAYORS, supra note 254, at 15-27.

347 CITY OF NEW HAVEN, www.cityofnewhaven.com (last visited Jan. 22, 2014).

348365 N.E.2d 1082, 1086 (Ill. App. Ct. 1977). 
that state law preempted any municipal ordinance or policy regarding the expungement of criminal records. Similarly, another Illinois appellate decision held that the state's interest in keeping track of convictions preempted city measures that erased convictions for qualified individuals who successfully completed an alternatives-to-adjudication program. ${ }^{349}$

In some cases, state laws may grant municipal courts limited powers to expunge or seal records of arrest or conviction for municipal ordinance violations. For example, Kansas law details circumstances under which municipalities may expunge convictions for violations of municipal

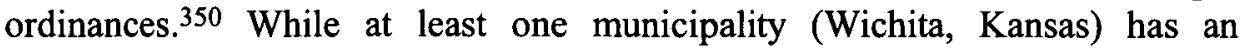
ordinance on its books detailing the circumstances under which a municipal court may expunge a record, it simply tracks the language of the state law granting this power to municipalities. ${ }^{351}$ Most municipalities in Kansas have only enacted varying fee schedules for expungement, rather than enacting the full language of the ordinance. This means that an applicant in Wichita pays $\$ 75$ to have a municipal ordinance violation expunged, ${ }^{352}$ compared to $\$ 115$ in Pittsburg, Kansas. ${ }^{353}$ While municipalities have generally not created expungement mechanisms for violations of local ordinances, such a scheme might well be possible for municipalities possessing the home-rule powers to enact criminal ordinances.

A more feasible option for municipalities might be to issue certificates or orders of limited relief from collateral consequences regarding municipal licenses, employment, or even housing restrictions. Section 10 of the UCCCA offers a model process by which municipalities could offer orders of limited relief from municipal collateral consequences based on the applicant's criminal history, need, and demonstrated absence of risk. While no municipality has yet enacted such a measure, it would provide significant options for relief from municipal collateral consequences for individuals seeking licensing, employment, or even housing in the local community. While creating such a system would require additional resources, it would enhance a sense of fairness and dignity by giving a voice to individuals with criminal convictions before imposing collateral consequences.

\section{Why "Ban the Box" Suggests Collateral Consequences Ordinances Will Succeed}

As criminal justice spending by local governments has continued to increase over the past two decades, more local decision-makers have begun to

349 People v. Vill. of Hanover Park, 724 N.E.2d 132, $144-45$ (Ill. App. Ct. 1999).

350 KAN. STAT. ANN. § 12-4516 (2012).

351 Wichita, Kan., Charter Ordinance 217 (Mar. 20, 2012).

352 WICHITA MUN. COURT, EXPUNGEMENT COVERSHEET 1 (2013), available at www.wi chita.gov/Government/Departments/Court/MunicipalCourtDocuments/Expungement $\% 20 \mathrm{Co}$ versheet\%202013.pdf.

${ }^{353}$ PITTSBURG, KAN., CODE § 1-7 (2011). 
support policies that reduce recidivism and address barriers to reentry for formerly incarcerated individuals. ${ }^{354}$ "Ban the Box" ordinances are an example of municipalities leading the way as policy innovators in the area of reducing unnecessarily harsh collateral consequences for people with criminal convictions. These ordinances began at the municipal level in 2004, with the first state following after at least twelve cities had implemented "Ban the Box" policies. 355 "Ban the Box" policies have proven much more popular among municipalities than anti-discrimination ordinances that protect individuals with criminal records. ${ }^{356}$ The success of "Ban the Box" policies suggests that municipalities may be willing to enact collateral consequences ordinances with the features discussed in the previous sections.

First, "Ban the Box" ordinances offer a precedent for municipalities in setting standards for when collateral consequences may be imposed based on an individual's criminal record. As discussed above, "Ban the Box" policies often outline standards for determining the relevance of a particular individual's record to a particular job. ${ }^{357}$ Although "Ban the Box" standards specifically apply to collateral consequences in employment, they can easily be translated to collateral consequences in areas such as municipal licensing. ${ }^{358}$

Although similar in many ways to anti-discrimination ordinances, "Ban the Box" ordinances go beyond the protections provided by anti-discrimination ordinances by laying out a specific hiring process and set of standards that must be followed to avoid employment discrimination on the basis of a criminal record. In addition to requiring changes to the initial application, "Ban the Box" policies may also require that qualified applicants rejected on the basis of their criminal records be provided with a copy of the record and an opportunity to rebut its accuracy or relevance. ${ }^{359}$ By offering concrete assurance to applicants that arrest or conviction records will not automatically disqualify them from consideration, "Ban the Box" policies encourage qualified individuals to apply who might be skeptical of the protections offered by anti-discrimination ordinances. ${ }^{360}$ Collateral consequences ordinances would also offer concrete procedural changes by committing governments to transparently document the collateral consequences they impose. In addition, publicizing these collateral consequences may increase pressure on municipalities to add procedural protections to ensure that collateral consequences are not imposed based on irrelevant or inaccurate records.

Compared to anti-discrimination ordinances, "Ban the Box" ordinances may offer fewer options for recourse for individuals who feel that they were


REENTRY 1 (2011); U.S. CONFERENCE OF MAYORS, supra note 254, at 1-4.

355 NAT'L EMP'T LAW PROJECT, supra note 257, at 2-9.

356 See supra Part III.C.2.

${ }^{357}$ Henry \& Jacobs, supra note 234, at 758.

358 See infra Part IV.B.2.

359 NAT'L EMP'T LAW PROJECT, supra note 257 , at 10-11.

360 See, e.g., id. at 8. 
wrongly denied employment. "Ban the Box" ordinances generally do not provide a private right of action. ${ }^{361}$ As a result, they may appeal to municipalities because they require fewer city resources than antidiscrimination ordinances, which generally require city human rights commissions to process and investigate claims. As "Ban the Box" ordinances have become more popular, however, they have begun to expand their reach in these areas: Buffalo, New York, recently passed a "Ban the Box" ordinance that covers private employers, includes a private right of action, and allows aggrieved individuals to file complaints with the city's anti-discrimination commission. ${ }^{362}$ Similarly, collateral consequences ordinances modeled on the UCCCA, like New Haven's, do not include a private right of action. While these ordinances do require resources to collect and update municipal collateral consequences, they do not require the resources or potential for liability of antidiscrimination ordinances.

The purpose of "Ban the Box" ordinances is not to blindly eliminate collateral consequences; instead, they recognize that criminal convictions may be relevant in certain employment situations and clearly delineate the standards for determining when such consequences should apply. This mitigating approach furthers what Michael Pinard has called a "dignity-based approach to collateral consequences" by offering individuals with criminal convictions an opportunity to be viewed on a level playing field with other applicants for employment. ${ }^{363}$ For municipalities that recognize the importance of treating individuals with criminal convictions with dignity and seek to reduce the economic impact of the cycle of incarceration, collateral consequences ordinances are a natural next step.

The decision by New Haven, Connecticut, to enact the first municipal collateral consequences ordinance followed the passage of a "Ban the Box" ordinance in $2009 .{ }^{364}$ The ordinance was drafted by the city's Reentry Initiative, working with the Yale Law School's Reentry Clinic, and approved by the mayor's office and the city's Corporation Counsel. Because the ordinance set standards for denying licenses based on prior convictions, advocates also worked closely with the city's Building Department (which issues licenses) and police chief (which approves or denies licenses based on a background check) to ensure their support. With the support of a coalition of reentry advocates, the ordinance passed New Haven's Board of Aldermen with unanimous support. The widespread popularity of the city's "Ban the Box" ordinance paved the way

361 See, e.g., SEATTLE, WASH., ORDINANCE 124201, § 14.17.030 (June 20, 2013), available at http://clerk.ci.seattle.wa.us/ archives/Ordinances/Ord_124201.pdf.

${ }^{362}$ Katharine H. Parker, Leslie E. Silverman \& Kelly Anne Targett, Buffalo's "Ban the Box" Ordinance Covers Private Employers, MONDAQ, June 26, 2013.

363 Pinard, Collateral Consequences, supra note 2, at 529.

${ }^{364}$ Press Release, City of New Haven, Board of Aldermen Votes Unanimously To Approve First in the Nation Collateral Consequences Ordinance (Apr. 2, 2012), available at http://www.cityofnewhaven.com/Mayor/ReadMore.asp?ID=\{92B20A3E-3EAB-4F91-9E440F6669B4AB41\}. 
for the passage of this groundbreaking ordinance. ${ }^{365}$ Just as the "Ban the Box" ordinance set standards for considering criminal records in employment, New Haven's collateral consequences ordinance set standards for considering criminal records in licensing and other types of municipal decision-making. The similarities between "Ban the Box" and collateral consequences ordinances also made it easier for advocates to explain the ordinance to aldermen, city department heads and other stakeholders, and the media.

Other cities have used anti-discrimination ordinances to prohibit the impermissible imposition of collateral consequences based on arrest or conviction records. Although states have not yet embraced the UCCCA, municipalities can lead the way on this issue by enacting collateral consequences ordinances on the local level. Municipal governments in communities with high rates of incarceration may more readily recognize the importance of reintegrating individuals with criminal convictions than state or federal governments. ${ }^{366}$ As with "Ban the Box" ordinances, municipalities can show that policies mitigating collateral consequences are manageable and popular before they filter up to the state level. ${ }^{367}$ For example, New Haven city government has already used the unanimous passage of the city ordinance as a tool in advocating for statewide collateral consequences legislation in Connecticut. 368

\section{CONCLUSION}

Although they are often overlooked by scholars and legal reformers, numerous collateral consequences of criminal convictions are imposed through city and county ordinances. The most serious and widespread municipal collateral consequences fall into four general categories: licensing ordinances, registration and exclusionary zones, local hiring policies, and third-party background-check requirements. Despite their lack of visibility, these local policies have been used as a way to exile "undesirable" populations by effectively barring them from residing, working, or participating in public life in their communities. Moreover, where exclusionary local ordinances have successfully withstood legal challenges, they often filter up to the state level.

Increased attention by local and state legislators to the issue of collateral consequences, particularly in employment, suggests that legislative reforms at the local as well as at the state level can help to mitigate this problem. At the state level, preemption laws can help to eliminate the patchwork of harsh restrictions on the most stigmatized populations, such as individuals required to

${ }^{365} \mathrm{Id}$.

${ }^{366}$ Taja-Nia Y. Henderson, Note, New Frontiers in Fair Lending: Confronting Lending Discrimination Against Ex-Offenders, 80 N.Y.U. L. REV. 1237, 1264 (2005).

${ }^{367}$ Paul Diller, Intrastate Preemption, 87 B.U. L. REV. 1113, 1119 (2007).

${ }^{368}$ Althea Marshall Brooks, Community Services Administrator of the City of New Haven, Testimony Submitted to the Judiciary Committee in Support of S.B. 1063, An Act Concerning the Uniform Collateral Consequences of Conviction Act (Mar. 11, 2013). 
register for sex offenses. At the local level, cities should follow the example of New Haven and the UCCCA in enacting innovative ordinances to mitigate unnecessarily harsh collateral consequences. The success of "Ban the Box" ordinances suggests that cities may lead the way as policy innovators for the states on the issue of collateral consequences. 